\title{
THE FISH FAUNA \\ OF THE TIMIŞ RIVER \\ (BANAT, ROMANIA)
}

Doru B $\breve{A N A} \breve{D U C} *$, Victor STROIL $\breve{A} *$
and Angela CURTEAN-BANADUC *

* "Lucian Blaga" University of Sibiu, Faculty of Sciences, Department of Ecology and Environment Protection, Dr. Ioan Raţiu Street 5-7, Sibiu, Sibiu County, Romania, RO-550012, ad.banaduc@yahoo.com, stroilavictor@yahoo.com, angela.banaduc@ulbs.ro

DOI: 10.2478/trser-2013-0040

KEYWORDS: lotic system, fish communities, spatial dynamic, habitats, human impact, trends, assessment.

\section{ABSTRACT}

This study assessed the fish communities' diversity and structure spatial dynamic in the Timiş River, in correlation with the biotope characteristics to establish management measures.

The results are based on quantitative fish samples from 21 stations of the Timiş River, situated between its sources and the Romanian-Serbian border $(241 \mathrm{~km})$. The sampling campaign was conducted during 2011-2012.

In the reference zone 32 fish species were identified, belonging to 27 genera and nine families. The fish associations present a high diversity along the entire Romanian sector of the Timiş River.

The fish communities' diversity distribution patterns reflect the biotope conditions diversity and the human impact factors presence and degree on the Timiş River sectors.

The fish communities' diversity assessment in correlation to biotope characteristics allows the establishment of priorities, objectives and measures for the sustainable management of the studied river biodiversity.

ZUSAMMENFASSUNG: Die Fischfauna des Timiș-Flusses (Banat, Rumänien).

Die Studie befasst sich mit der Untersuchung der Diversität, räumlichen Struktur und Dynamik der Fischgemeinschaften im Timiș-Fluss in Verbindung mit den Merkmalen des Lebensraums im Hinblick auf $\mathrm{zu}$ ergreifenden Maßnahmen für ein entsprechendes Management.

Die Ergebnisse beruhen auf qualitativen Erfassungen an 21 von den Quellen bis zur serbischen Grenze im Timiş-Fluss entlang einer Strecke von $241 \mathrm{~km}$ verteilten Probestellen. Die Probeentnahme erfolgte während des Jahres 2011-2012.

In der Referenzzone wurden 32 Fischarten identifiziert, die zu 27 Gattungen und neun Familien gehören. Die Fischgemeinschaften weisen eine hohe Diversität entlang der gesamten rumänischen Strecke des Timiș auf.

Die Verteilungsmuster der Fischgemeinschaften widerspiegeln die Kennzeichen der Diversität der Lebensraumbedingungen und das Vorhandensein und Maß menschlicher Eingriffsfaktoren an den untersuchten Strecken des Timiș-Flusses.

Die Erfassung der Diversität der Fischgemeinschaften in Verbindung mit den Biotopcharakteristika erlaubt die Festlegung von Prioritäten, Objektiven und Messungen für ein nachhaltiges Management der Biodiversität des untersuchten Flusses. 
REZUMAT: Ihtiofauna râului Timiş (Banat, România).

Acest studiu a evaluat diversitatea şi dinamica spațială a comunităților de peşti din râul Timiş̧, în corelație cu caracteristicile de biotop pentru stabilirea măsurilor de management.

Rezultatele se bazează pe probe cantitative de peşti din 21 de stații situate de-a lungul râului Timiş, între izvoare şi granița româno-sîrbă $(241 \mathrm{~km})$. Campania de prelevare a probelor a fost realizată în 2011-2012.

În zona de referință, au fost identificate 32 specii de peşti, aparținând la 27 genuri şi nouă familii. Asociațiile de peşti prezintă o diversitate ridicată de-a lungul întregului sector românesc al râului Timiş.

Modelele de distribuție a diversității comunităților de peşti reflectă diversitatea condițiilor de biotop, prezența şi gradul factorilor de impact antropic asupra sectoarelor râului Timiş.

Evaluarea diversitătii comunităților de peşti în corelație cu caracteristicile de biotop, permite stabilirea priorităților, obiectivelor şi măsurilor pentru un management sustenabil a râului studiat.

\section{INTRODUCTION}

The Timiş River is the main lotic system of the south-west region of Romania, being the largest river of the Banat area, with a total basin surface of 5,795 $\mathrm{km}^{2}$ and $241 \mathrm{~km}$ length in the Romanian national territory and its lowest part in Serbia.

From the ichtiological point of view it was studied only in the 60 's of the last century (Bănărescu, 1964).

The Timiş River springs area is located in the eastern part of the Semenic Mountains, in the proximity of Piatra Goznei Peak (1,145 m altitude), flowing and passing through mountainous, hilly and lowland areas. This river is actually formed by the confluence of four upper streams Semenic, Grădiştei, Brebu Nou and Pârâul Lung.

The upper part of the Timiş River basin includes the eastern slopes of the Banat Mountains, the western slopes of Ţarcu Mountains - Muntele Mic and Poiana Ruscă mountains and Timiş-Cerna corridors (Oancea and Velcea, 1987).

The middle-lower basin includes lower altitudes relief units like Lugojului Hills, the Pogănişului Hills, Lugoj Plain and Timiş Plain (Badea and Bugă, 1992).

The Timiş River lower basin is contained in the Serbian territory. (INMH, 1971; Udo et al., 2011; Arba et al., 2013; Ujvari, 1972; Linc, 2002; Ştef and Costea, 2006).

Usually such large lotic systems should be ecologically assessed/monitored as often as it is possible, for their biodiversity conservation and lotic associated services management, and for the riverine human communities' welfare.

With significant human negative impact effects since the XVII Century, this river varies a lot from almost pristine sectors/habitats to heavily impacted ones. The only exhaustive information regarding the ichthyofauna of Timiş River originates before 1960 (Bănărescu, 1964). An update of this information is absolutely necessary in order to be able to achieve an actual river-wide management plan with regard to the fish population.

This study aims to inventory and assess the fish fauna status of the Timiş River in Romania, from its headwaters to the national Romanian-Serbian border, to identify the human activities with significant impact on this important conservative and economic taxonomic group and to suggest management measures. 


\section{MATERIAL AND METHODS}

This ichthyological study was conducted along the whole Romanian length of the Timiş River (Fig. 1), from its mountainous springs area to the Romanian-Serbian border, during 2011-2012. The fish samples were taken in every season, the paper presenting the total average aboundances of quantitative captures of every sampling section.

Quantitative and qualitative (q) seasonal repeated samples made possible the provision of an updated list of fish species with populations considered permanent, structural balanced and therefore stable, to the extent to which human activities conducted in the future will not change their certain parameters.

In the present fish assemblage survey, through time (one hour) on effort unit, quantitative samples were taken in 21 sampling stations (Fig. 2), with an Aquatech IG 600, 30 A, 0.65/1.2 kw, electrofishing device in the upper sectors and with an IG 1300, $60 \mathrm{~A}, 2.6 \mathrm{kw}$, electrofishing device in the middle-lower river course. The fishing team consisted of the same number of members in all the sampling stations to assure a similar effort of sampling during each time period, and comparable results among the stations.

The studied sampling stations were chosen according to: the valley morphology, the type of river substratum and the human impact presence bias (riverine land use, hydro-technical works, substrate mineral exploitation, urban and industrial pollution sources).

The fish were identified, counted and released at once back in their habitat for conservation reasons.

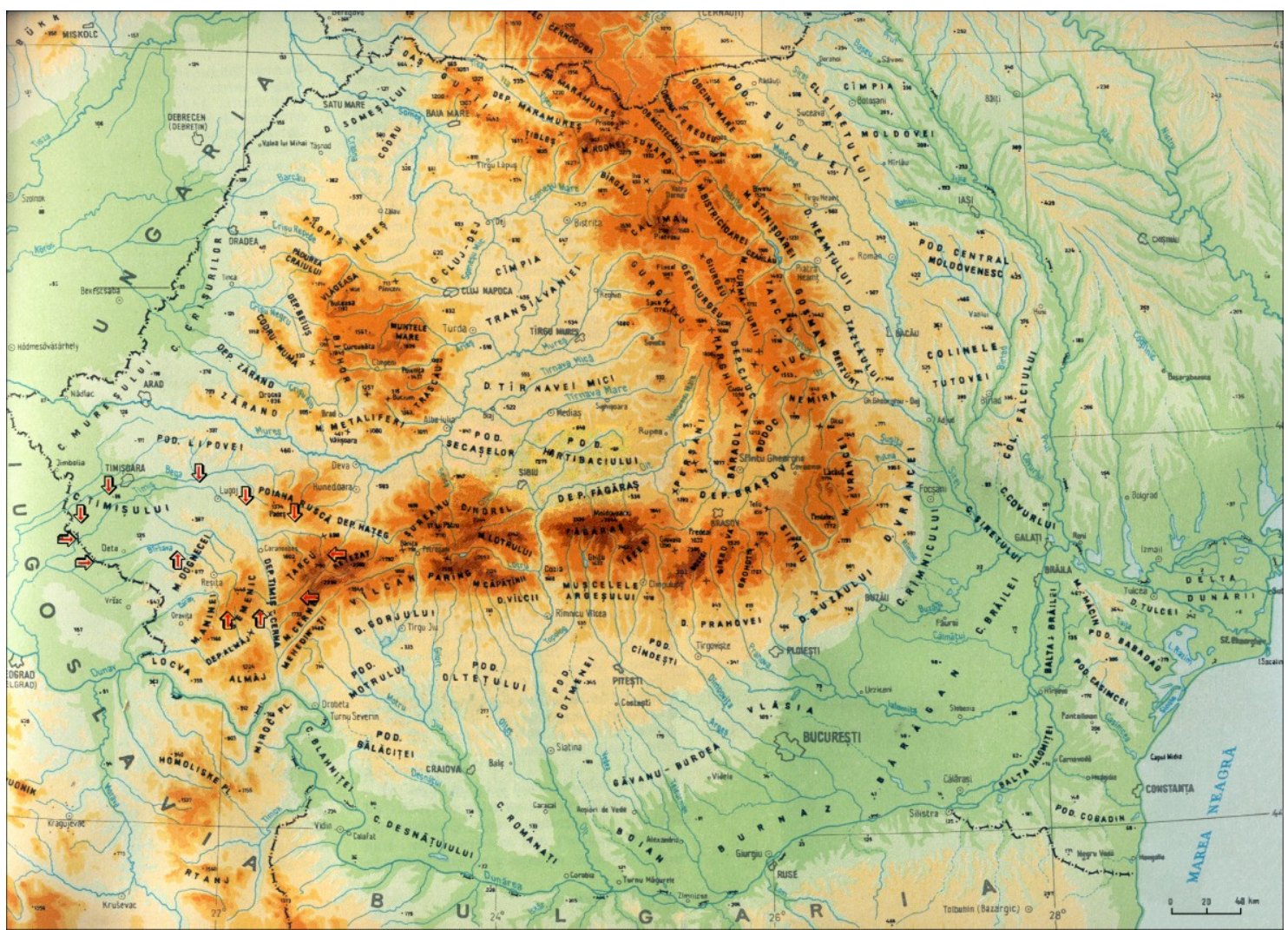

Figure 1: Timiş River basin localization (Romanian sector) 


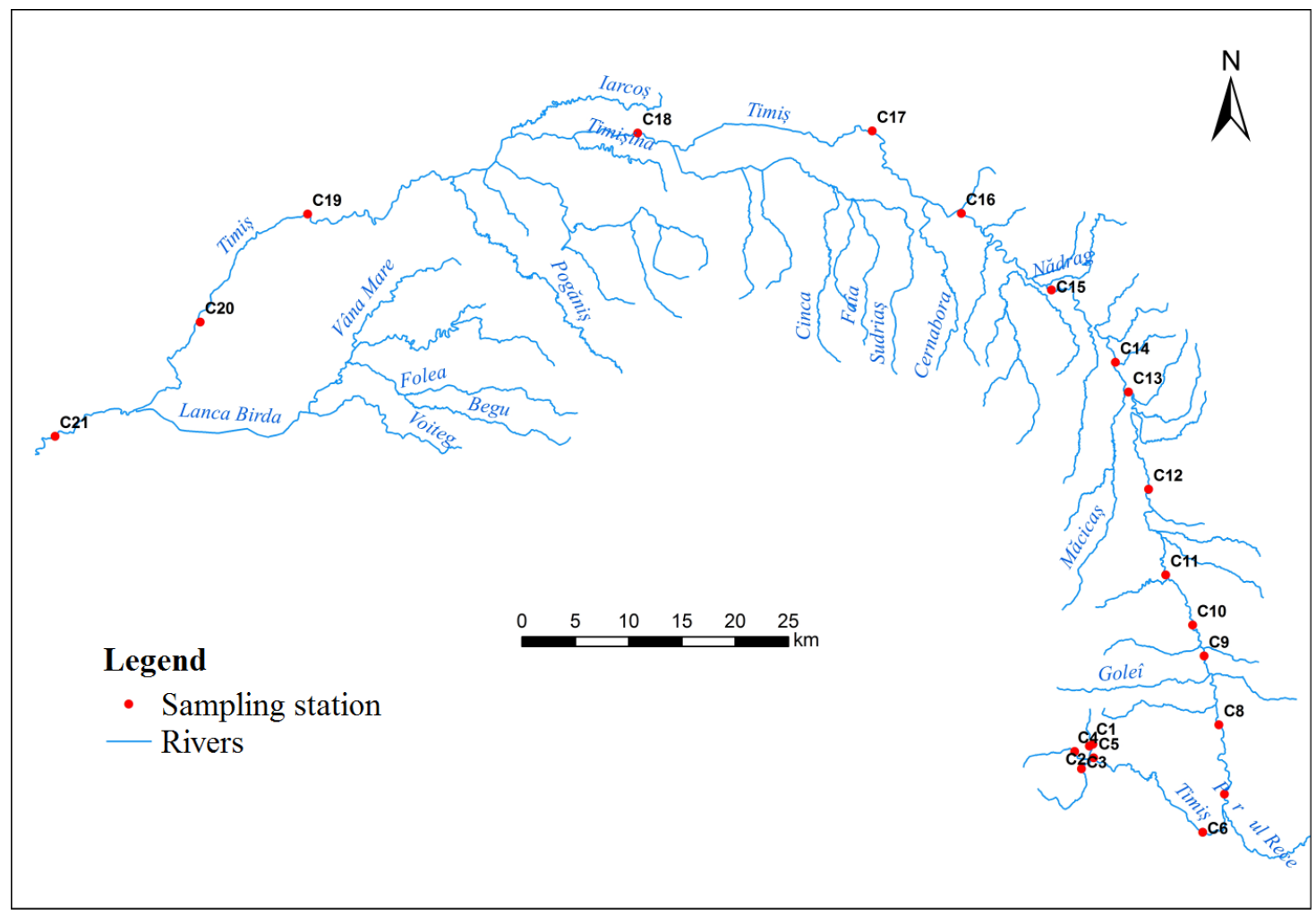

Figure 2: Fish sampling stations (C1-21) on Timiş River.

\section{RESULTS}

The studied biological material consists of the following Cyclostomata and Osteichthyes species: Eudontomyzon danfordy Regan, 1991; Eudontomyzon vladykovi Oliva and Zanandrea, 1959 (q - qualitative sample); Salmo trutta Linnaeus, 1758; Salvelinus fontinalis (Mitchill, 1814); Thymallus thymallus (Linnaeus, 1758); Esox lucius Linnaeus, 1758 (q); Rutilus rutilus (Linnaeus, 1758) (q); Squalius cephalus (Linnaeus, 1758) ; Phoxinus phoxinus (Linnaeus) 1758; Tinca tinca (Linnaeus, 1758) (q); Scardinius erythrophthalmus (Linnaeus, 1758); Leuciscus aspius (Linnaeus, 1758) (q); Alburnus alburnus (Linnaeus, 1758); Alburnoides bipunctatus (Bloch, 1782); Vimba vimba (Linnaeus, 1758); Chondrostoma nasus (Linnaeus, 1758); Rhodeus sericeus (Pallas, 1776); Gobio gobio (Linnaeus, 1758); Romanogobio uranoscopus (Agassiz, 1828); Romanogobio albipinnatus (Lukasch, 1933); Romanogobio banaticus (Bănărescu 1960); Pseudorasbora parva (Temminck and Schlegel, 1846); Barbus barbus (Linnaeus, 1753); Barbus meridionalis Risso, 1827; Cyprinus carpio Linnaeus 1758; Carasius auratus (Linnaeus, 1758); Barbatula barbatula (Linnaeus, 1758); Cobitis taenia Linnaeus 1758; Sabanejewia balcanica (Karaman, 1922); Silurus glanis Linnaeus 1758 (q); Ameiurus nebulosus (Lesueur, 1819) (q); Lota lota (Linnaeus, 1758); Lepomis gibbosus (Linnaeus, 1758); Perca fluviatilis Linnaeus, 1758; Gymnocephalus cernua (Linnaeus, 1758); Gymnocephalus schraetzer (Linnaeus, 1758); Zingel streber (Siebold, 1863); Zingel zingel (Linnaeus, 1766) and Cottus gobio Linnaeus 1758.

The four streams (Brebu Nou, Lung, Semenic and Grădişte) form the man-made Trei Ape/Three Waters Lake. The downstream sector of the rock-fill dam forms the Timiş River. These have a different ichtyofauna because they have different characteristic of habitats and because they suffered different effects caused by the human presence along time. 
The Semenic Stream (C1 sampling station) with typical mountain habitats (Fig. 3) has a typical mountain dominant fish fauna: Salmo trutta (45\%), Phoxinus phoxinus (25\%) and Eudontomyzon danfordy (10\%), fish species that show a good quality of this stream; and secondary fish species coming from the near Trei Ape Lake: Squalius cephalus $(15 \%)$ and Perca fluviatilis (5\%). The values represent the average of total abundances obtained in each trip of ichtyofauna sampling in this section.

The relatively difficult car access in this stream area and the inclusion in the Semenic-Cheile Caraşului National Park of this lotic system, respectively the subsequent inclusion of this area also in the Natura 2000 European network by designating here a Natura 2000 site also with the name Semenic-Cheile Caraşului, currently offers very good protection (mainly due to its relative geographic isolation) to mountain ichthyofauna of this stream.

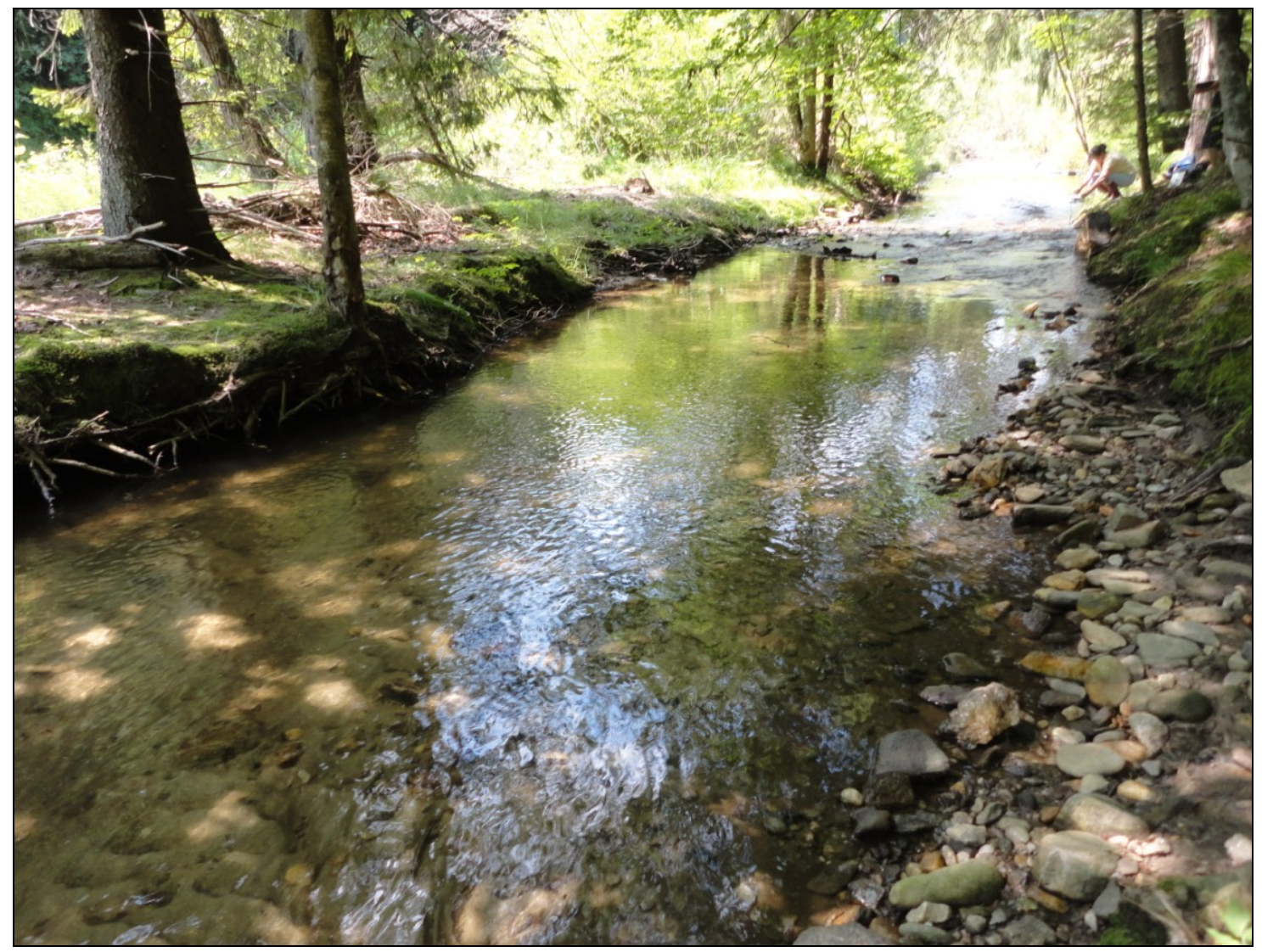

Figure 3: Characteristic Semenic Stream habitat with $500 \mathrm{~m}$ upstream its flow into Trei Ape/Three Waters Lake.

However, an exception with negative effects is the practice of drawing/transporting the cut trees/logs directly in riverbed.

The future increasing accessibility on the local roads can be a threat for this river fish fauna too. 
The Brebu Nou Stream (C2) (Fig. 4) and Lung Stream (C3) (Fig. 5), both flowing into the Trei Ape/Three Waters man-made lake, at a distance of few tens of meters, in the proximity of Brebu Village, with less mountainous geomorphological characteristics and a long lasting anthropogenic impact on banks and terraces (deforestation, grazing and colmatation) have strongly influenced the local lotic habitats and ichthyofauna by species that have proliferated in the downstream lake after the lake formation. Thus, although Salmo truta is still there (5.56\% in Brebu Nou Stream and 6.98\% in Lung Stream), as in the period before the formation of the lake, it is in the minority in favor of Phoxinus phoxinus $(13.89 \%$ in Brebu Nou Stream and 62.79\% in Lung Stream), Squalius cephalus (77.78\% in Brebu Nou Stream) and Perca fluviatilis (2.78\% in Brebu Nou Stream and $30.23 \%$ in Lung Stream). Eudontomyzon danfordy disappeared here.

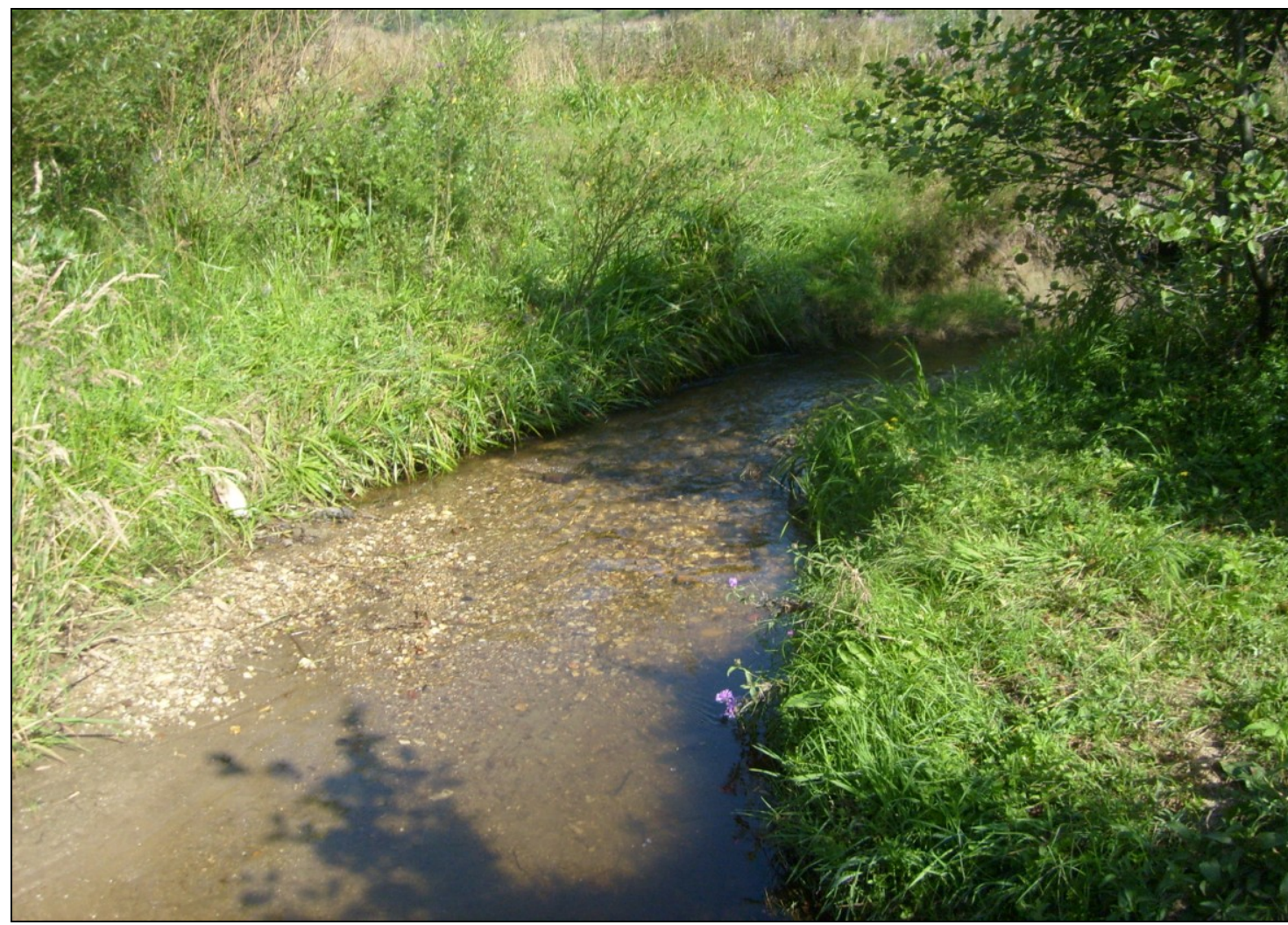

Figure 4: Brebu Nou stream characteristic habitat $500 \mathrm{~m}$ upstream the Trei Ape Lake.

Especially the population of Salmo truta fario, a species of economic interest, it may grow again, and that of Eudontomyzon danfordy, a species of conservation interest, can be reintroduced and can recovers if these rivers management would consider creating physical barriers (small dams of wood) to stop the upstream constant movement of species of fish characteristic for the Trei Ape lake (minnow, chub and perch) and the increase of permanent shading of banks by planting coniferous trees to decrease the water average temperature.

Also, the water quality must be protected by the local (Brebu locality) households and on adjacent lands waste waters which flows in these two small streams and to reduce the sediment deposition in the riverbed based on some riverine vegetation protection. The lack of the antierosional measures on the banks (Fig. 5) and slopes and the presence of small water pools for cows water supply (Fig. 6) affected the river habitats and salmonids. 


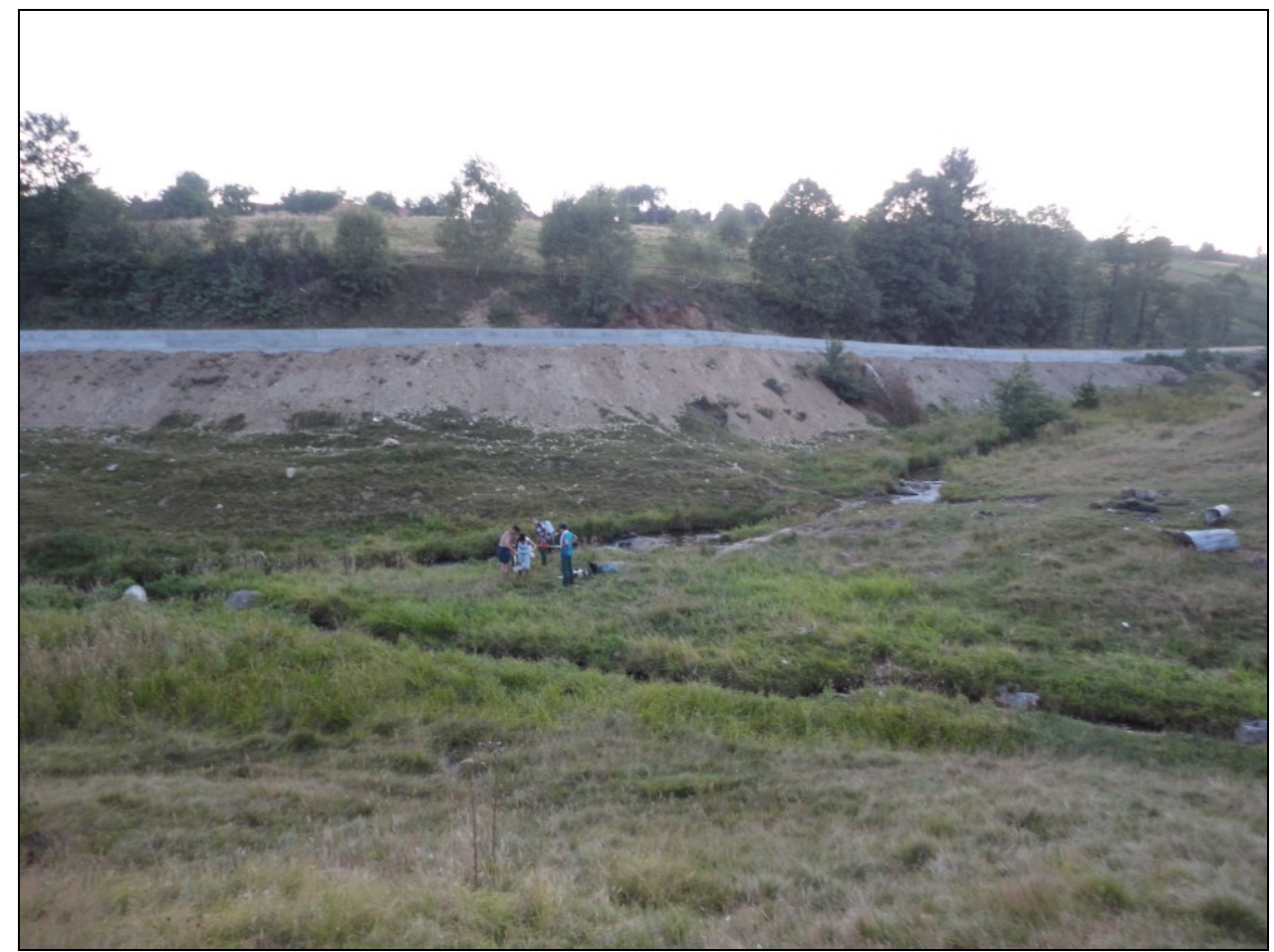

Figure 5: Loose slopes, on the roadside of Brebu-Slatina Timiş near the Lung Stream, increase sedimentation and habitats degradation impact on salmonids.

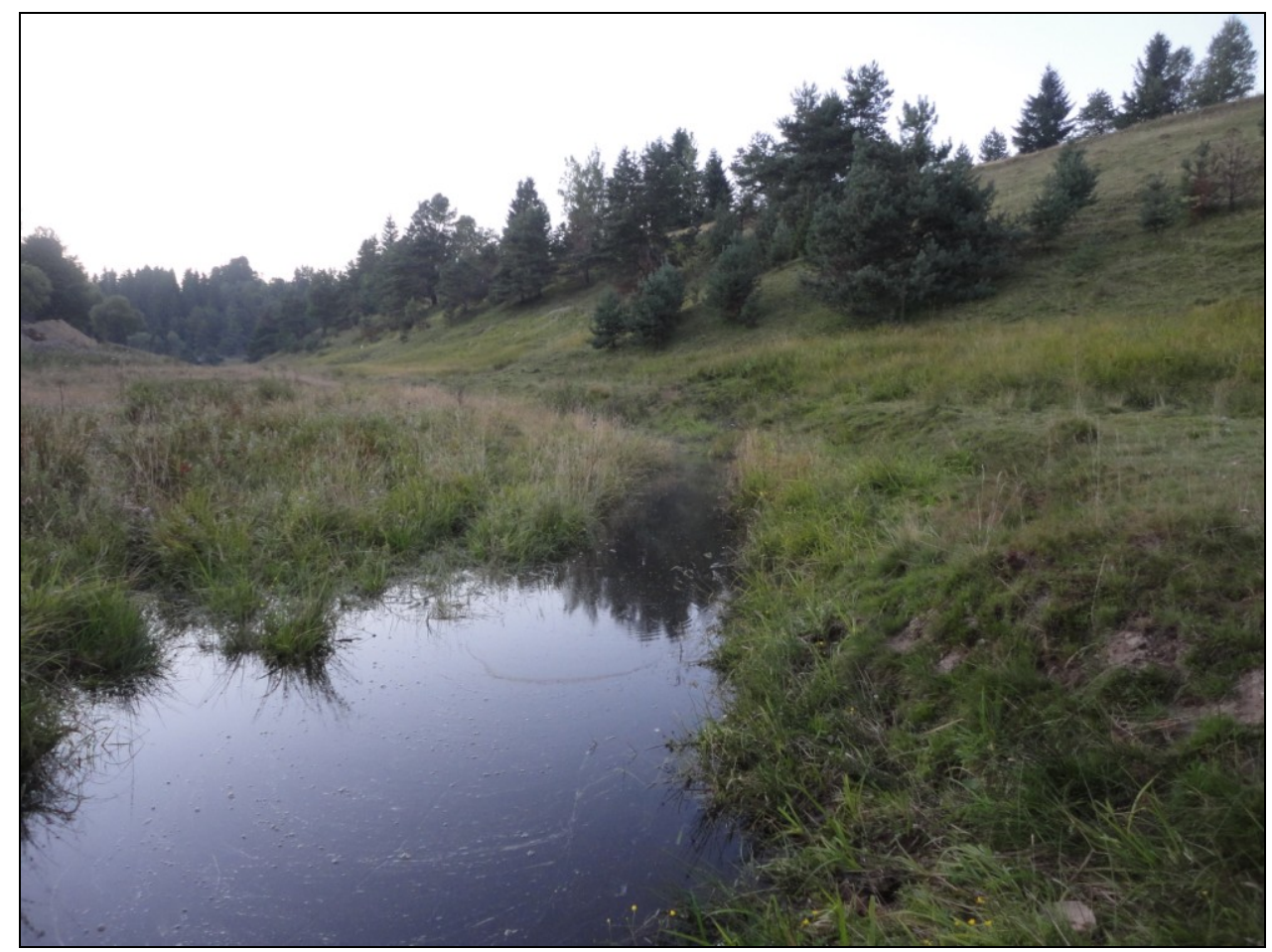

Figure 6: Lenitic sector transformed from lotic sector, for cattle water reservoires use. 
In terms of habitat conditions and ichthyofauna, the last analyzed of the four tributaries that form the Trei Ape Lake, Grădişte Stream (C4) (Fig. 7) has intermediate characteristics for the first three tributaries analyzed so far. Here are present the species: Squalius cephalus (62.5\%), Eudontomyzon danfordi (12.5\%), Phoxinus phoxinus (12.5\%) and Perca fluviatilis (12.5).

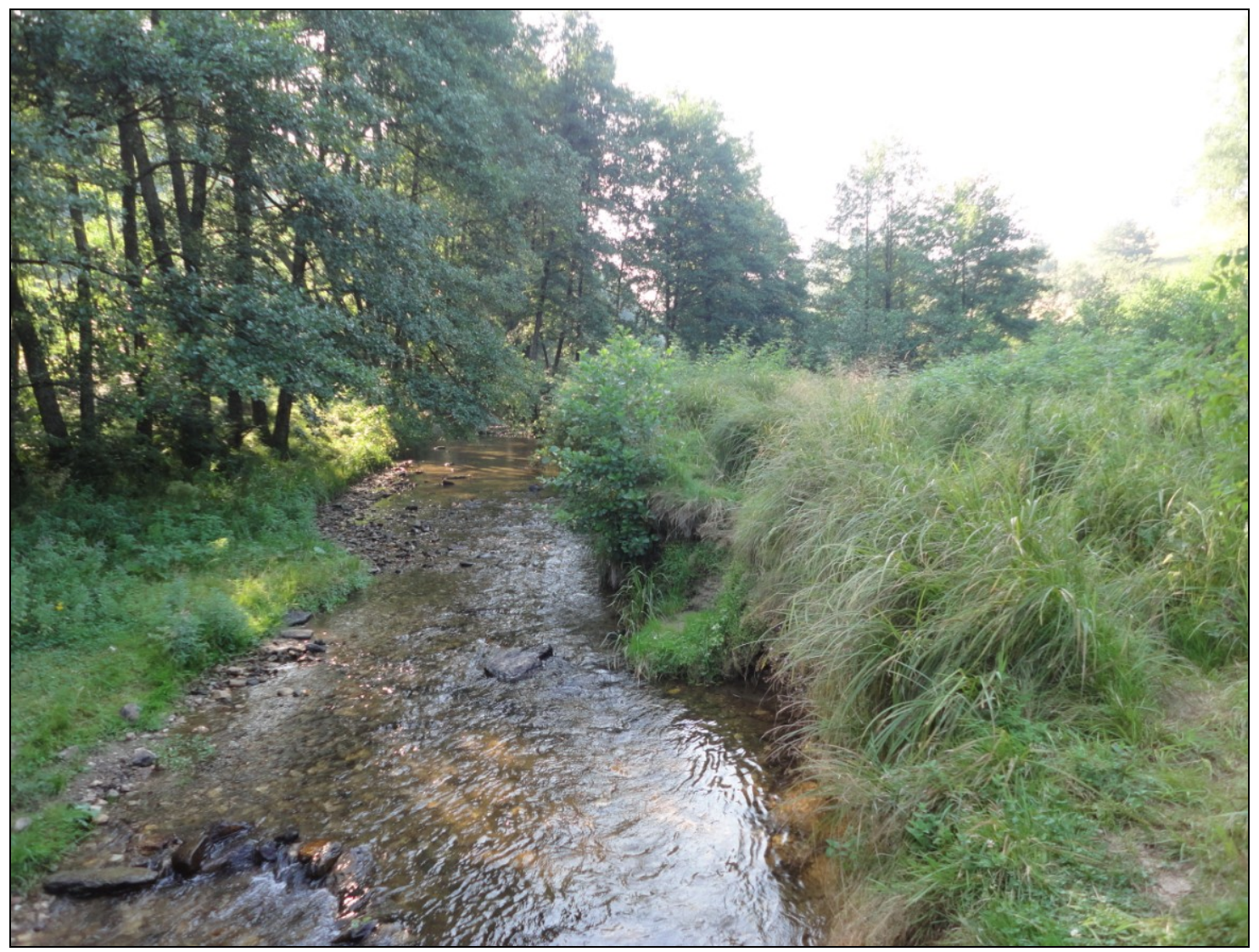

Figure 7: Characteristic habitat for the Grădişte Stream.

For the preservation of the natural habitats and ichthyocenoses, here, as in Lung and Brebu Nou streams cases, would be of interest to build a small wooden dam at the river confluence with the Trei Ape Lake, to prevent the upstream advancement of the lenitic fish species (the minnow, the chub and the perch) and pressure on typical mountain/lotic species (the sucker fish), important under conservative aspects.

There are also required to implement management measures for the Gărâna Village waste waters and poaching control.

The numerical increasing with $66 \%$ of the alien cyprinids in this lotic systems area, situation induced by the Trei Ape Lake (Fig. 8) lotic discontinuum (Fig. 9), makes that the four tributaries which form the lake, where the river springs now, need a proper management of mountain fish species of conservative or economically interest, because we cannot count on the inputs of fresh genetic material from downstream. 


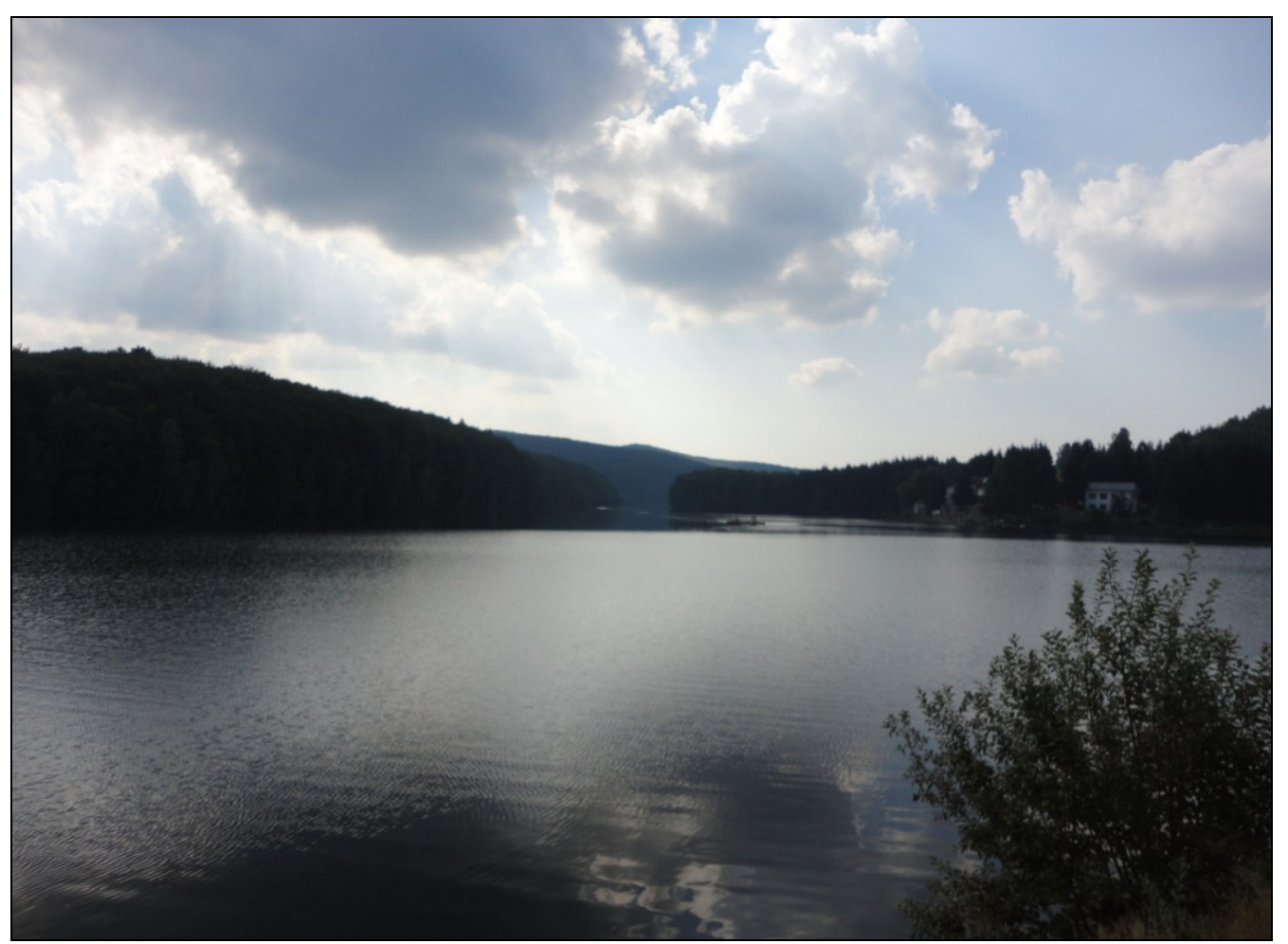

Figure 8: The lotic discontinuum due to Trei Ape/Three Waters Lake, view from the dam.

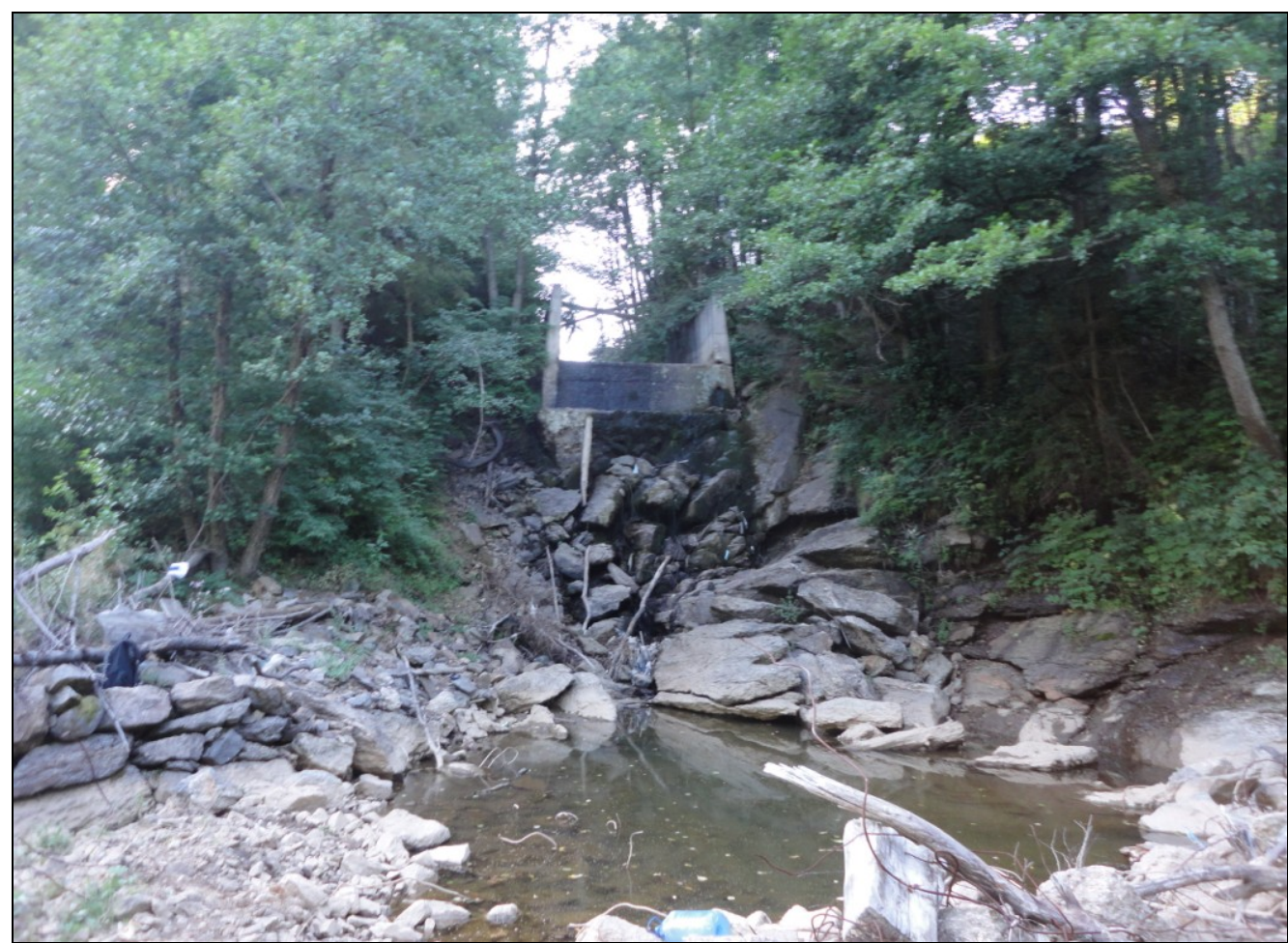

Figure 9: The lotic discontinuum due to Three Waters Dam - the overflow spilway of the dam. 
In the sampling sector located at $\mathbf{5 0 0} \mathbf{m}$ downstream the rockfill dam of the Trei Ape Lake (C5) were registered the following total abundances: Squalius cephalus (37.78\%), Salmo trutta (35.56\%), Perca fluviatilis (13.33), Phoxinus phoxinus (8.89\%) and Eudontomyzon danfordy (4.44\%).

Salmo trutta fario, Eudontomyzon danfordy and Phoxinus phoxinus reveal the natural mountain habitat and the Timiş River ichthyofauna here; Leuciscus cephalus and Perca fluviatilis show the direct influence of the habitat and ichthyofauna of Trei Ape Lake (Fig. 8).

The low water flow regime (Fig. 10), especially in periods of drought, still allow the existence of populations of Salmo trutta fario and Eudontomyzon danfordyi under former natural potential of this sector of the river, the individuals sampled from the holes in the substrate of the riverbed, where they retreat after periods of floods, by overflow outlets of the lake or they may come from downstream during their migration towards the upstream.

The water passage under the dam is made by iron pipes, the iron deposits causing an impact (Fe sedimentation) covering the invertebrate microhabitats, the fish trophic base.

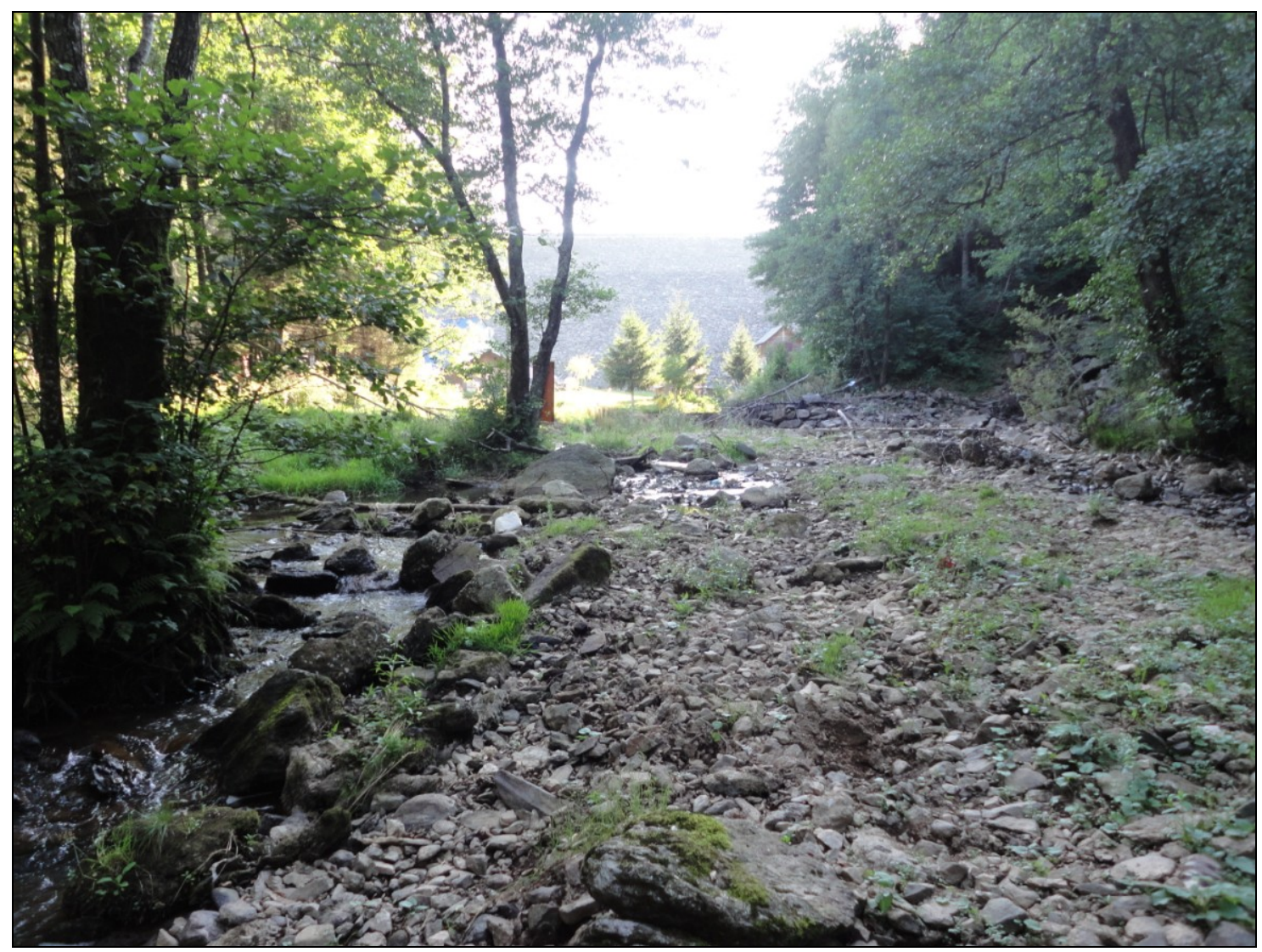

Figure 10: River habitat downstream the Trei Ape/Three Waters Dam.

For the remote area of Timiş between Trei Ape Dam and Teregova, it is worth mentioning the presence of an individual of Eudontomyzon vladikovy (q), a species of high conservative importance, the Timiş River basin being the only watershed where this fish have been lately still found in Romania. Together with this very rare species were also found Eudontomyzon danfordyi, Salmo trutta fario and Phoxinus phoxinus, revealing good local habitat conditions. 
One km upstream the Teregova locality in sub-mountain habitats (C6) (Fig. 11) were collected the following species: Phoxinus phoxinus (38.57\%), Cottus gobio (30\%), Barbatula barbatula (24.29\%), Edontomyzon danfordy (1.43\%), Salmo trutta (1.43\%), Alburnoides bipunctatus (1.43\%), Barbus meridionalis $(1.43 \%)$ and Squalius cephalus (1.43\%). The presence of fish species characteristic for the downstream sector (Alburnoides bipunctatus, Leuciscus cephalus and Barbus meridionalis) is determined by the modified lotic habitats in semi-lenitic areas, habitats altered (Fig. 12) for water supply of a local mill.

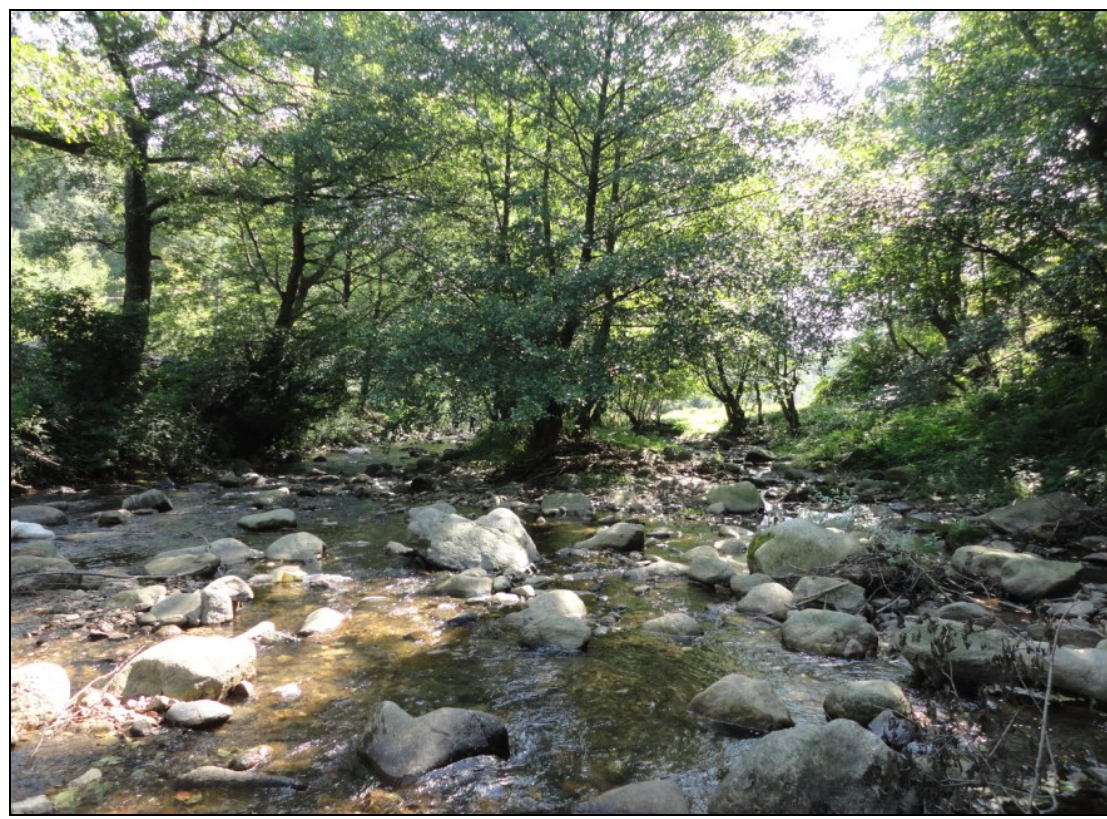

Figure 11: Characteristic habitat for the Timiş River at $2 \mathrm{~km}$ upstream Teregova locality.

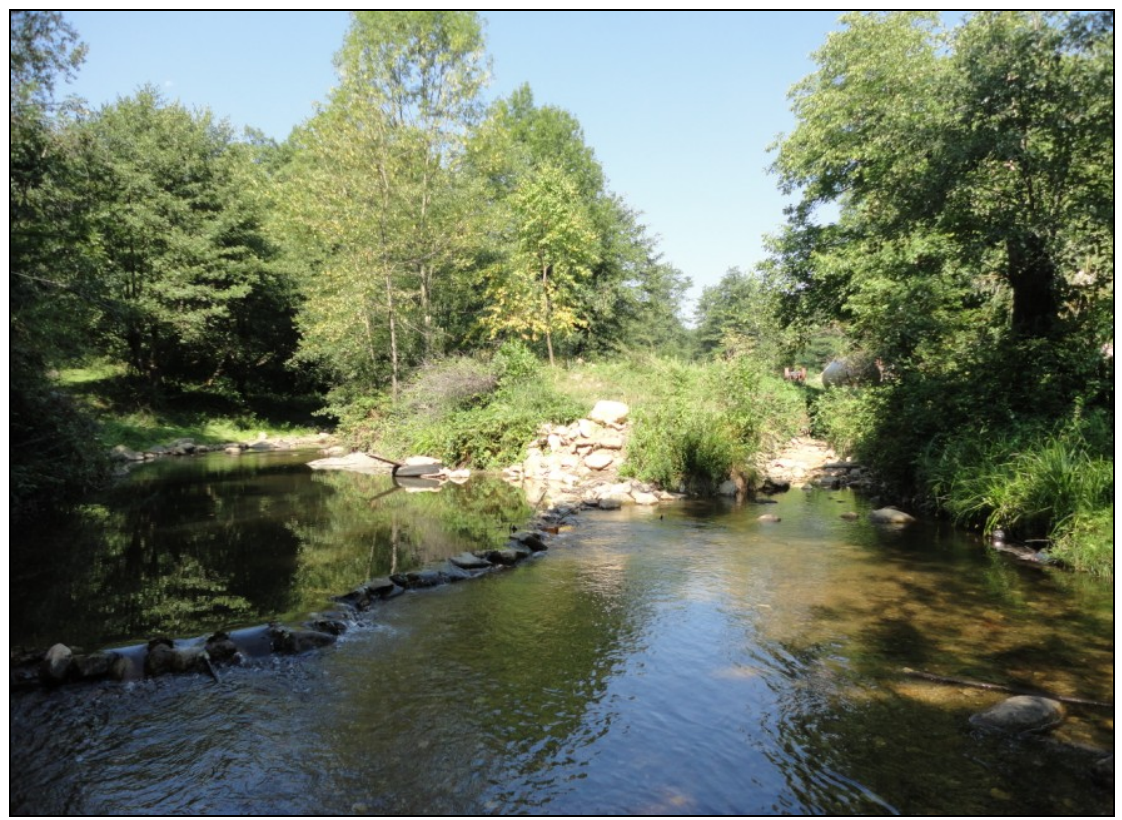

Figure 12: Anthropogenically altered habitat at $1 \mathrm{~km}$ upstream of the Teregova locality. 
In the sampling station located in the Teregova Gorges $(\mathbf{C} 7)$, at $2 \mathrm{~km}$ upstream from the Armeniş locality were obtained the following total abundances: Barbatula barbatula (26.98\%), Eudontomyzon danfordy (22.22\%), Barbus meridionalis (22.22\%), Phoxinus phoxinus (11.11\%), Pseudorasbora parva (4.76\%), Romanogobio uranoscopus (3.17), Alburnoides bipunctatus (1.59\%), Squalius cephalus (1.59\%), Salvelinus fontinalis (1.59\%), Thymallus thymallus (1.59\%), Cottus gobio (1.59\%) and Chondrostoma nasus (1.59\%).

Eudontomyzon danfordi (very frequent and active in this river sector - Fig. 13), Salmo trutta fario, Salvelinus fontinalis, Thymallus thymallus, Cottus gobio, Phoxinus phoxinus, Orthrias barbatulus, reveal the sub-mountainous character of this sector of the Timiş River and the following (Barbus meridionalis, Gobio uranoscopus, Alburnoides bipunctatus, Leuciscus cephalus and Chondrostoma nasus) reveal the continuity and natural influence of downstream ichthyological sectors.

Although with a specific very complex structure and a balanced age structure of the ichthyofauna, which shows a very good condition of this lotic sector, the presence of the invasive fish species Pseudorasbora parva can show that the biocenosis condition is not optimal, since this foreign species was able to create an ecological niche and remain viable in this area.

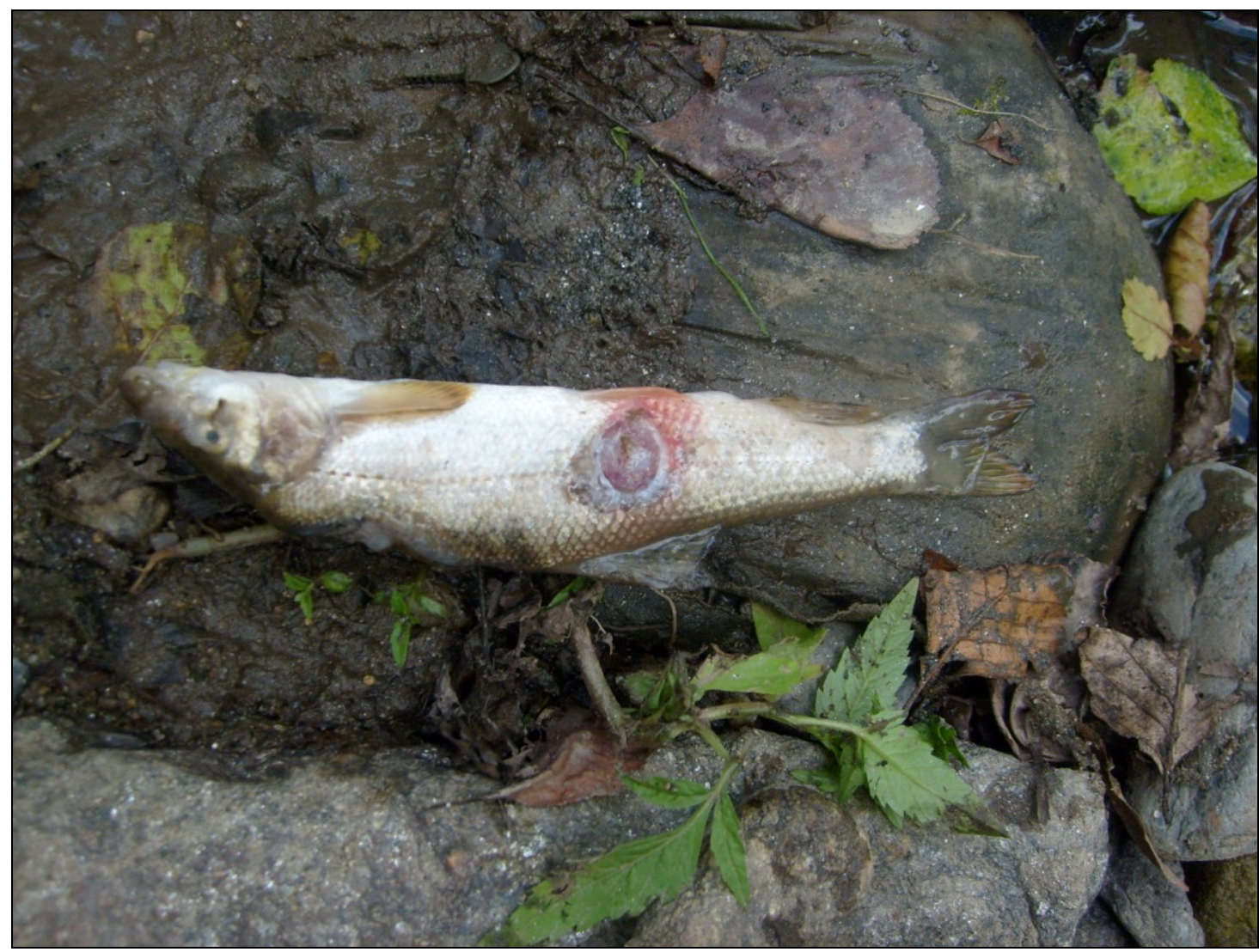

Figure 13: The traces of the place where was set a sucker flish on a Mediterranean barbell. 
In the sampling sector (Fig. 14) located $0.5 \mathrm{~km}$ upstream of the Sadova Veche Village (C8) were collected and identified the following species: Barbus meridionalis $(37.5 \%)$, Alburnus alburnus (16.67\%), Cottus gobio (13.89\%), Phoxinus phoxinus (8.33\%), Squalius cephalus (6.94\%), Alburnoides bipunctatus (6.94\%), Barbatula barbatula (4.17\%), Eudontomyzon danfordi (1.39\%), Romanogobio uranoscopus (1.39\%), Chondrostoma nasus $(1.39 \%)$ and Sabanejewia balcanica (1.39\%). The quantitative aspects of ichthyological samples can reveal a liquid flow mismanagement due to hidrotechnical works in the proximity eastern main tributaries basins (Râul Rece and Feneş). Also there are information about ongoing poaching.

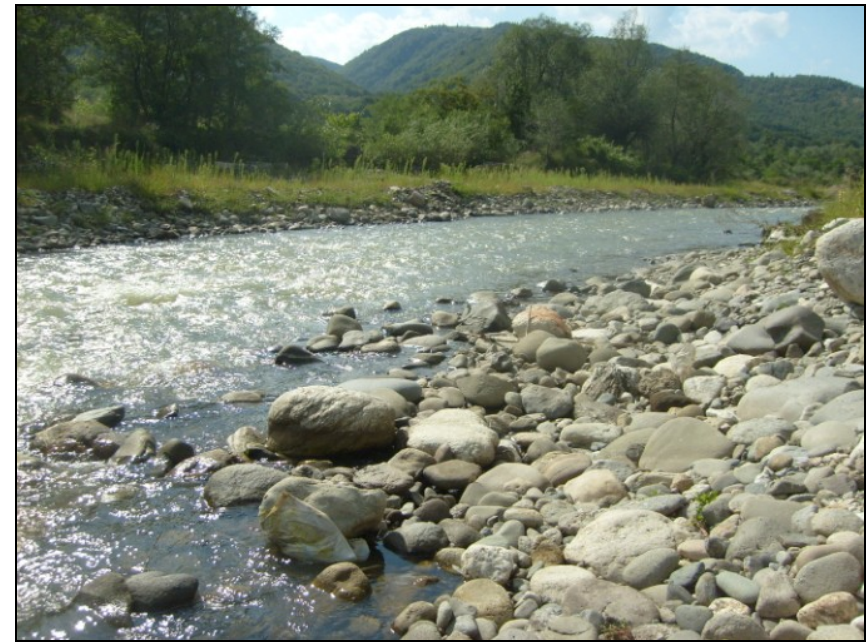

Figure 14: Timiş River characteristic lotic habitat near Sadova Veche locality.

In the sampling area located upstream of Bucoşniţa Village (Fig. 15) (C9) were collected and identified the following species: Eudontomyzon danfordy (1.45\%), Squalius cephalus (1.45\%), Alburnus alburnus (13.04\%), Alburnoides bipunctatus (5.8\%), Gobio gobio (5.8\%), Romanogobio uranoscopus (1.45\%), Barbus meridionalis (44.93\%), Barbatula barbatula (5.8\%), Sabanejewia balcanica (8.7\%), Cottus gobio (8.7\%), Phoxinus phoxinus $(1.45 \%)$ and Chondrostoma nasus $(1.45 \%)$. Poaching is practiced in the area.

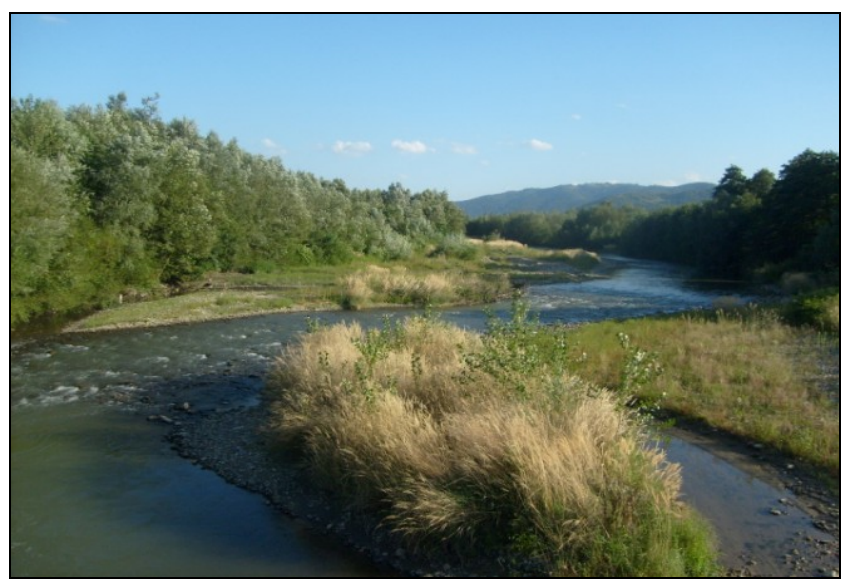

Figure 15: Characteristic habitat for Timiş River, in the proximity of Bucoşniţa locality. 
In the sampling area located near the village Petroşniţa (C10) (Fig. 16) were collected and identified the following species: Sabanejewia balcanica (27.87\%), Alburnus alburnus (18.03\%), Romanogobio uranoscopus (14.75\%), Barbus meridionalis (14.75\%), Barbatula barbatula (11.48\%), Squalius cephalus (4.92\%), Eudontomyzon danfordy (1.64\%), Alburnoides bipunctatus (1.64\%), Gobio gobio (1.64\%), Chondrostoma nasus (1.64\%) and Cottus gobio (1.64\%). There is information about intensive poaching, including with electricity.

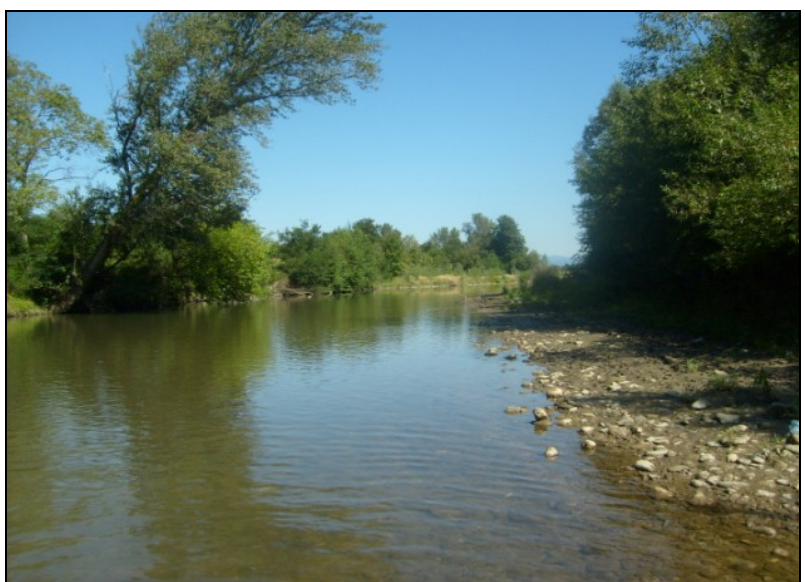

Figure 16: Characteristic habitat for Timiş River, in the proximity of Petroşniţa locality.

In the sampling area located in the locality Buchin (Fig. 17) (C11) were collected and identified the following species: Barbus meridionalis (79.59\%), Alburnus alburnus (4.08\%), Romanogobio uranoscopus (4.08), Barbatula barbatula (4.08\%) Squalius cephalus (2.04\%), Alburnoides bipunctatus (2.04\%), Chondrostoma nasus (2.04\%) and Sabanejewia balcanica $(2.04 \%)$. The over $50 \%$ numerical reduction of fish species in comparison with older data (Bănărescu, 1964), although the vast majority of species are missing in this sector, it is in the areas located immediately upstream and immediately downstream is due to mismanagement of the mining of minerals from this river sector. It should be noted that scientific knowledge is necessary for these operations to grow aquatic biodiversity, but not to decrease it. But the investors or local administrations should contact the proper biodiversity specialists to achieve this goal required of the coexistence of financial gain with protection of natural resources including biodiversity.

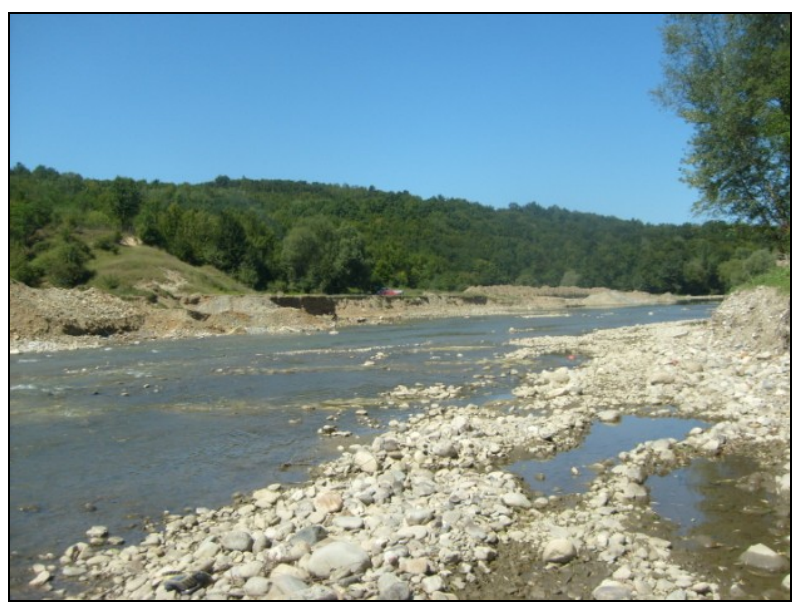

Figure 17: Lotic habitat adversely affected by a poor management of minerals exploitations. 
In the sampling station located at Caransebes locality (Figs. 16, 17 and 18), upstream of Jupa Village (C12) were obtained the following total abundances: Barbus meridionalis (48.28\%), Barbatula barbatula (18.97\%), Romanogobio uranoscopus (12.07\%), Squalius cephalus (6.9\%), Sabanejewia balcanica (5.17\%), Rhodeus sericeus (1.72\%), Romanogobio banaticus (1.72\%), Alburnus alburnus (1.72\%), Alburnoides bipunctatus (1.72\%), Chondrostoma nasus (1.72\%), Esox lucius (q).

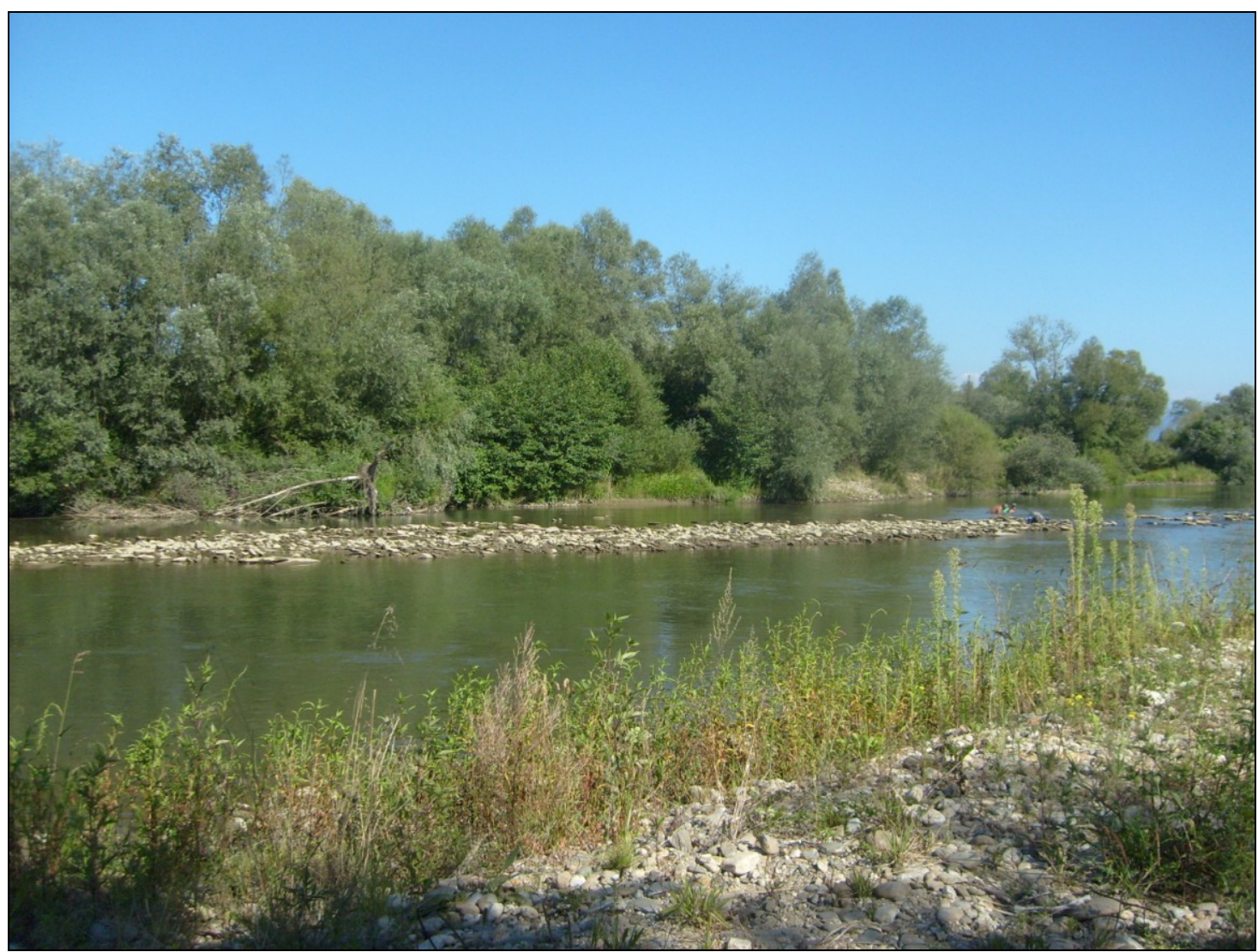

Figure 16: Typical habitat for Timiş River, downstream from the town Caransebeş.

The total abundances of captured and identified species in this sector has shown the existence in the area of Barbus meridionalis, species penetrated here only in recent decades that has replaced the Barbus barbus, which now appears only downstream (P. M. Bănărescu, in verbis). Also from the values of total abundances transpires the negative impact of the locality Caransebeş, organic pollution (Fig. 17) and not only, and habitat modification due to minerals exploitation (Fig. 18) poorly designed embankments of the banks, largely damage of the corridors of tree vegetation on the banks of Timiş River, which induce changes in some main physico-chemical parameters of water, such as temperature, oxygenation, light penetration in the water, etc., the liquid and solid flow regime change due to inlet of other flows with different characteristics from other river basins (upper Bistra Mărului River water is passed in the Timiş River tributary, the Sebeş River, which confluence in Caransebeş); for example, this can be the reason of Barbus barbus replacement with Barbus meridionalis. 


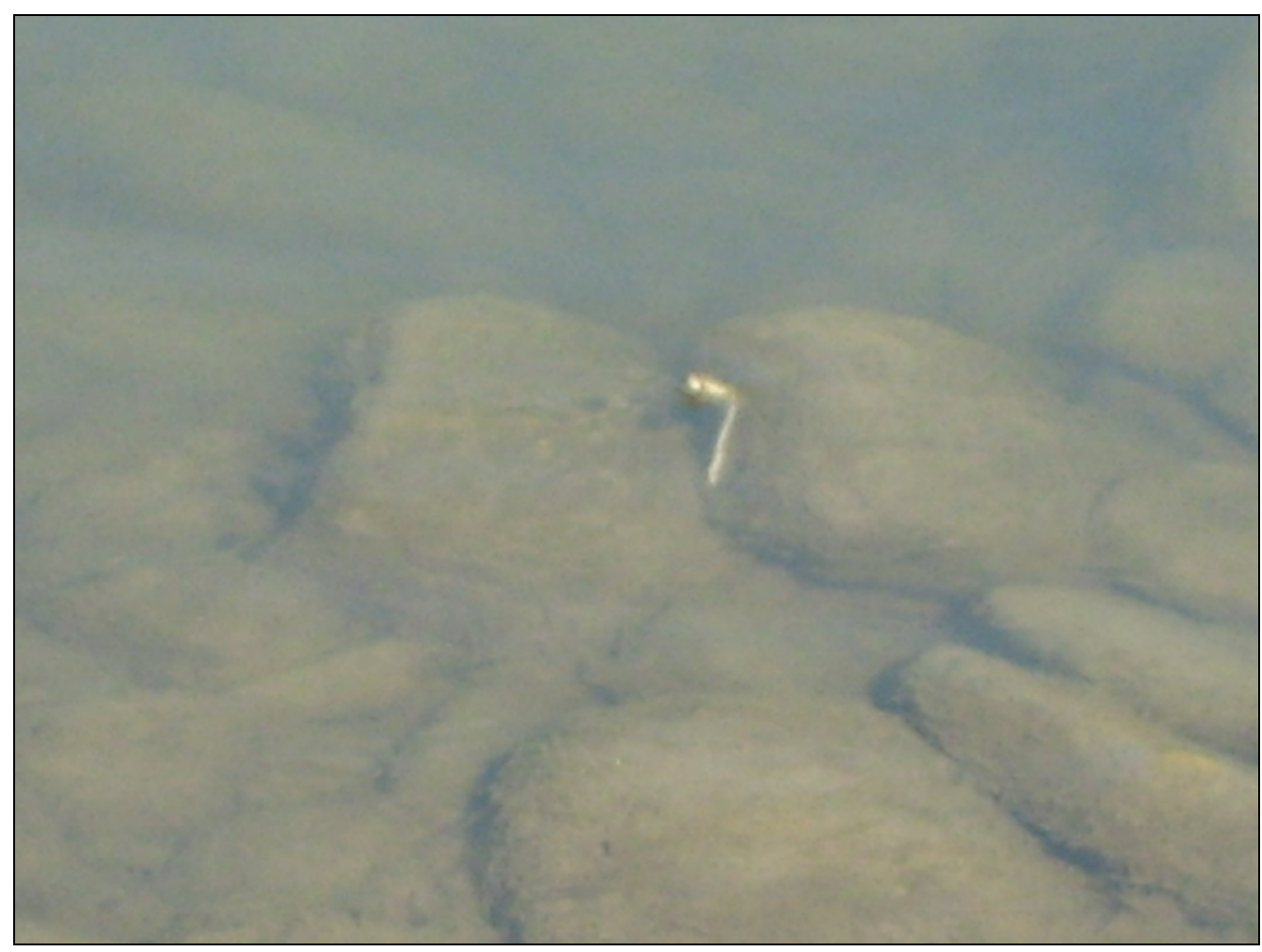

Figure 17: Organic load deposited on the substrate of the riverbed - detail.

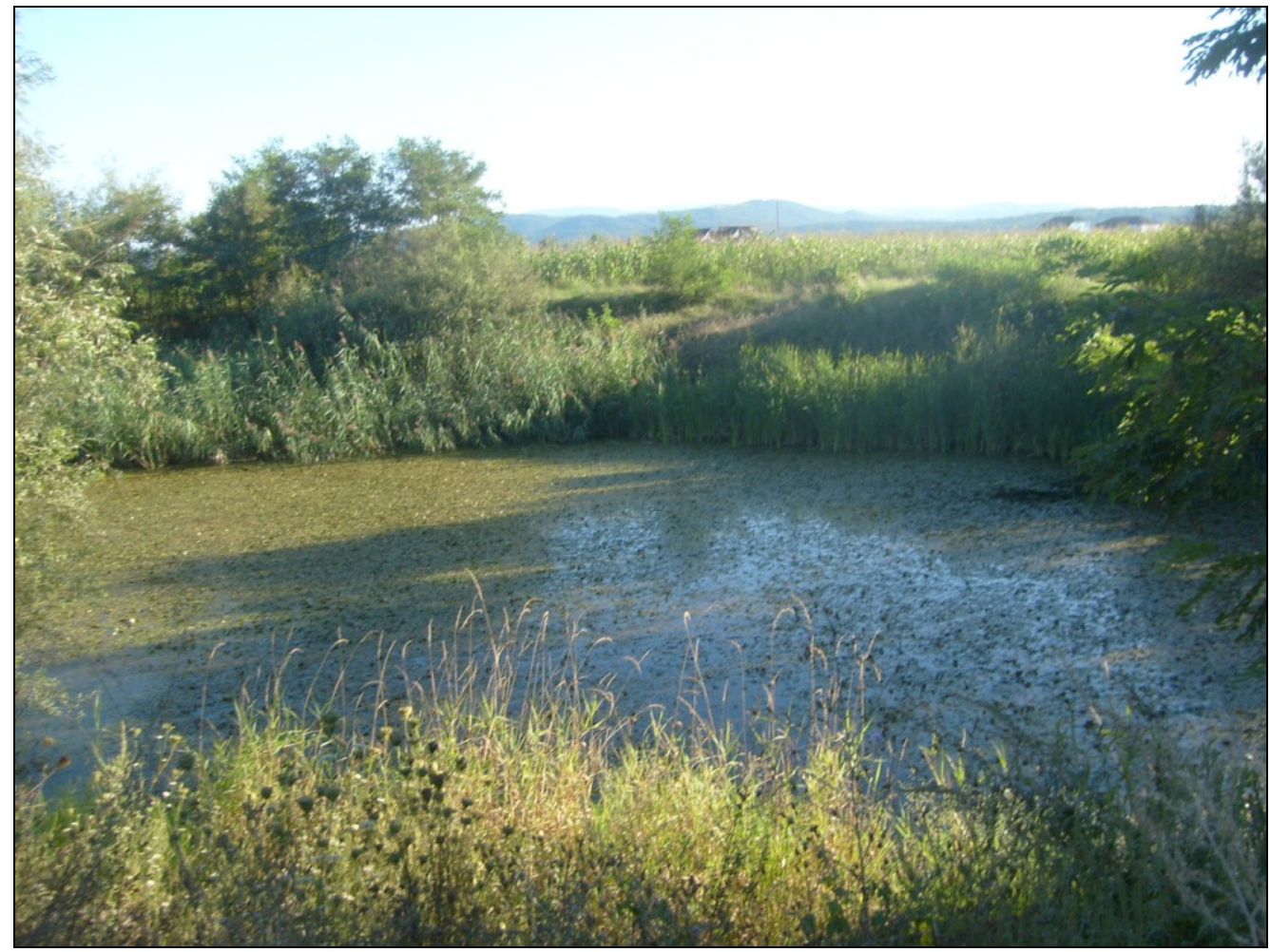

Figure 18: Anthropogenic lentic environments in the proximity of the Timiş riverbed. 
In the sampling area located near the locality Peştere (C13) (Fig. 19) were collected and identified the following species: Barbus meridionalis (23.16\%), Barbatula barbatula (22.11\%), Alburnus alburnus (12.63\%), Alburnoides bipunctatus (8.42\%), Romanogobio uranoscopus (8.42\%), Squalius cephalus (6.32\%), Romanogobio banaticus (5.26\%), Sabanejewia balcanica (5.26\%), Phoxinus phoxinus (5.26\%), Chondrostoma nasus (1.05\%), Rhodeus sericeus (1.05\%), Gobio gobio (1.05\%), Squalius aspius (q) and Esox lucius (q). The sector is relative far from human impact, being proposed by the authors in the Biogeographic seminars for Romania and Bulgaria (helded in "Lucian Blaga" University of Sibiu, Sibiu/Romania, 2008) to be part of the Natura 2000 site of the upstream Timiş.

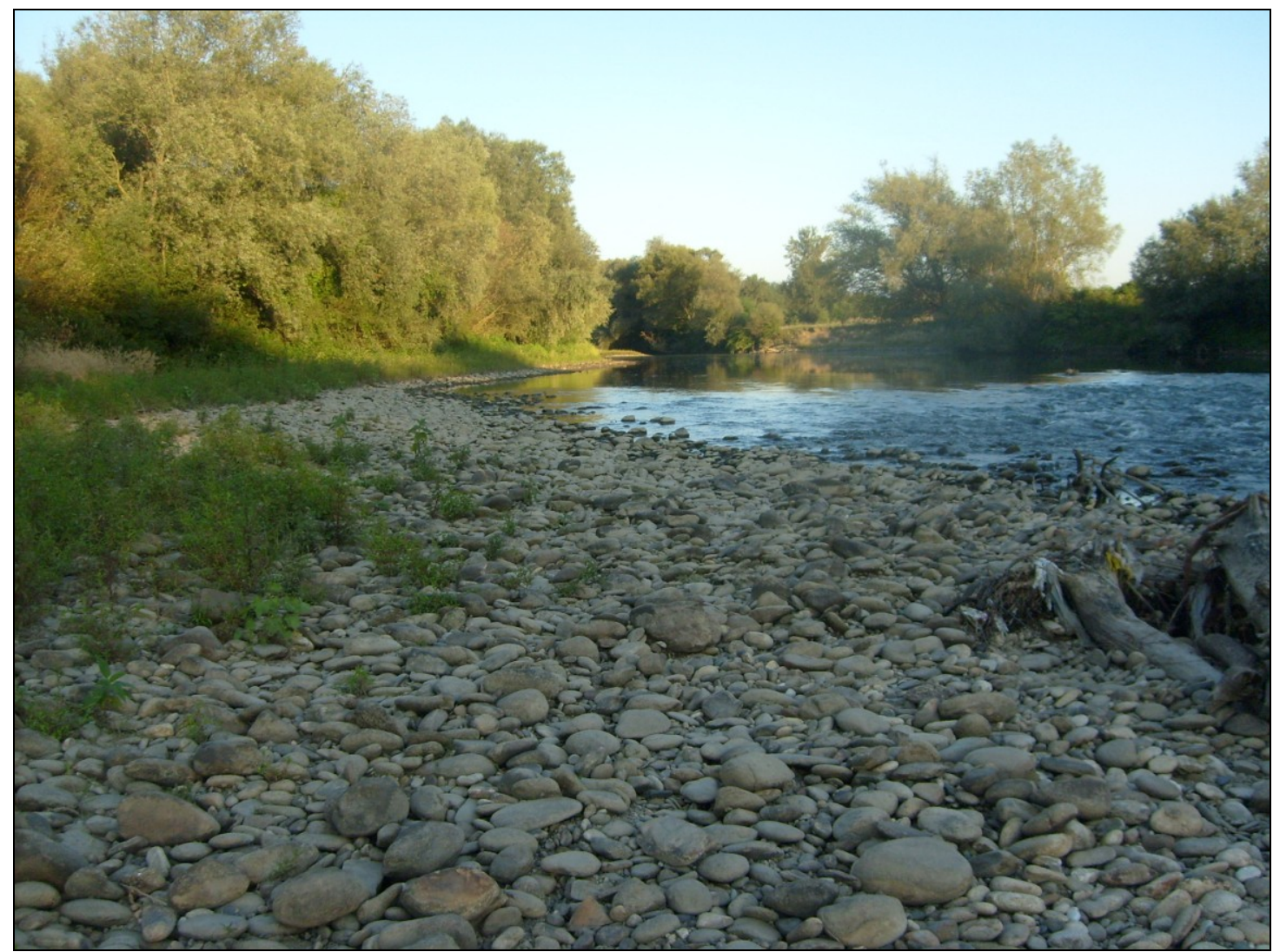

Figure 19: Characteristic habitat for Timiş River, in the sector of Peştere locality.

In the sampling area located in the proximity of the locality Constatin Daicoviciu (the former Căvăran locality) (C14) (Figs. 20 and 21), were collected and identified the following species: Barbatula barbatula (27.4\%), Alburnus alburnus (15.07\%), Romanogobio uranoscopus (9.59\%), Gobio gobio (9.59\%), Alburnoides bipunctatus (9.59\%), Squalius cephalus (6.85\%), Romanogobio banaticus (5.48\%), Phoxinus phoxinus $(5.48 \%)$, Sabanejewia balcanica (5.48\%), Rhodeus sericeus (4.11\%), Chondrostoma nasus (1.37\%), Squalius aspius (q) and Esox lucius (q). 


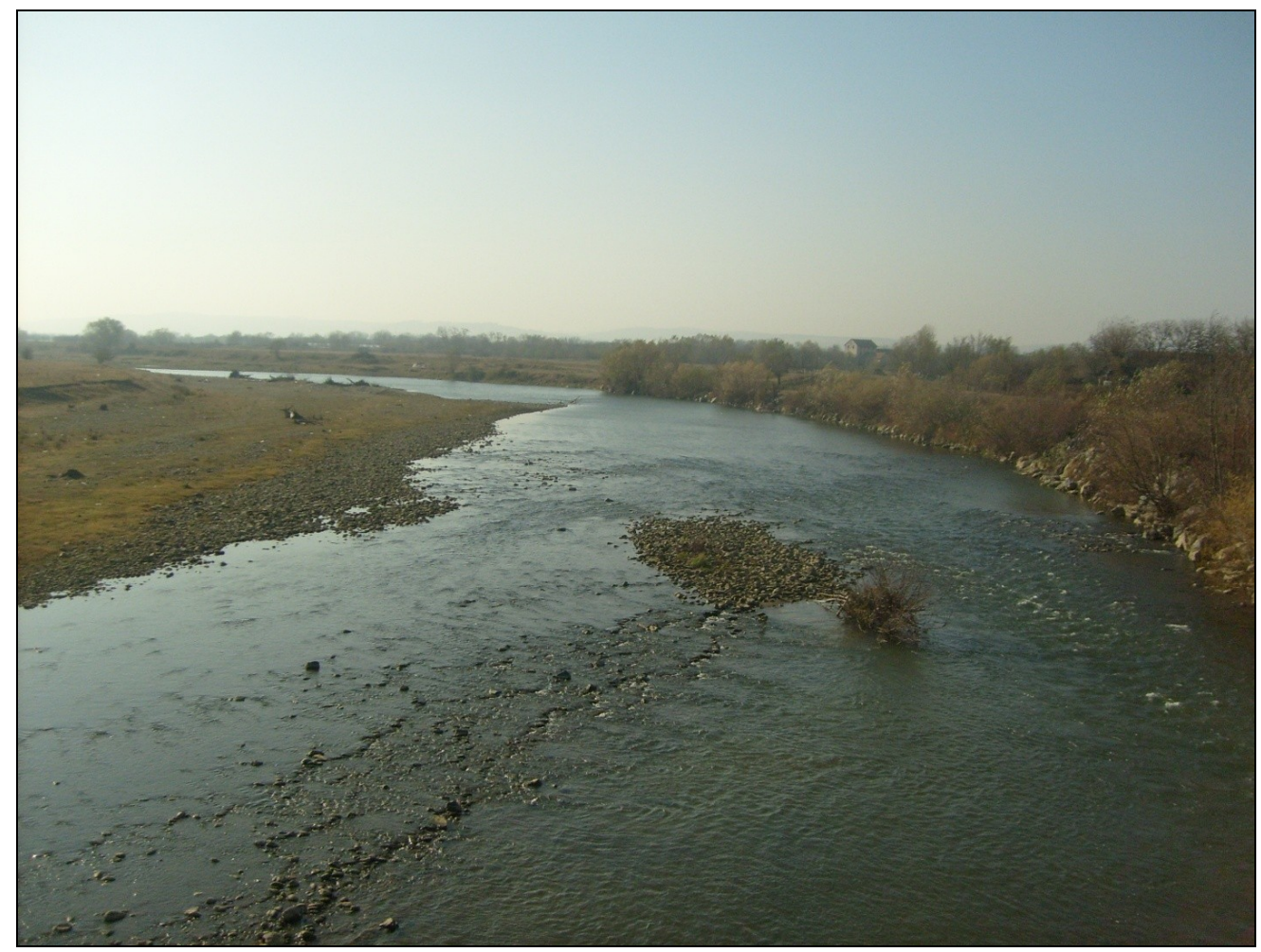

Figure 20: Characteristic habitat for Timiş River at Constantin Daicoviciu locality.

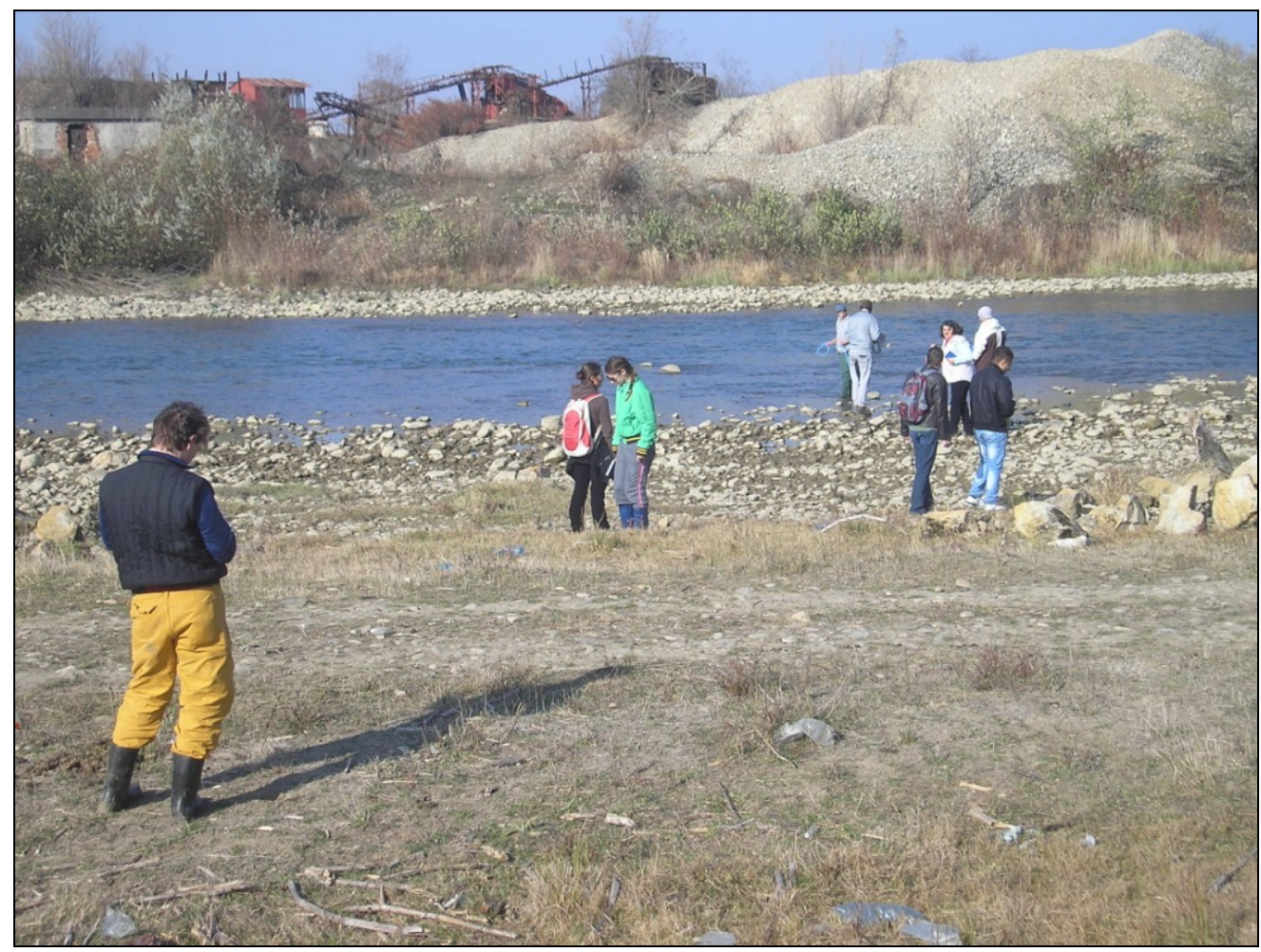

Figure 21: Habitat affected by mining ballast at Constantin Daicoviciu locality. 
In the sampling area located in the proximity of the locality Jena $(\mathbf{C 1 5})$ were collected and identified the following species: Alburnus alburnus (40\%), Gobio gobio (20\%), Alburnoides bipunctatus (20\%) and Squalius cephalus (20\%). The decreasing of the number of species is due to aggressive (intensive and extensive) exploitation of the substrate of the riverbed (Figs. 22 and 23), which actually led even to lowering the groundwater levels in this sector till downstream Lugoj locality.

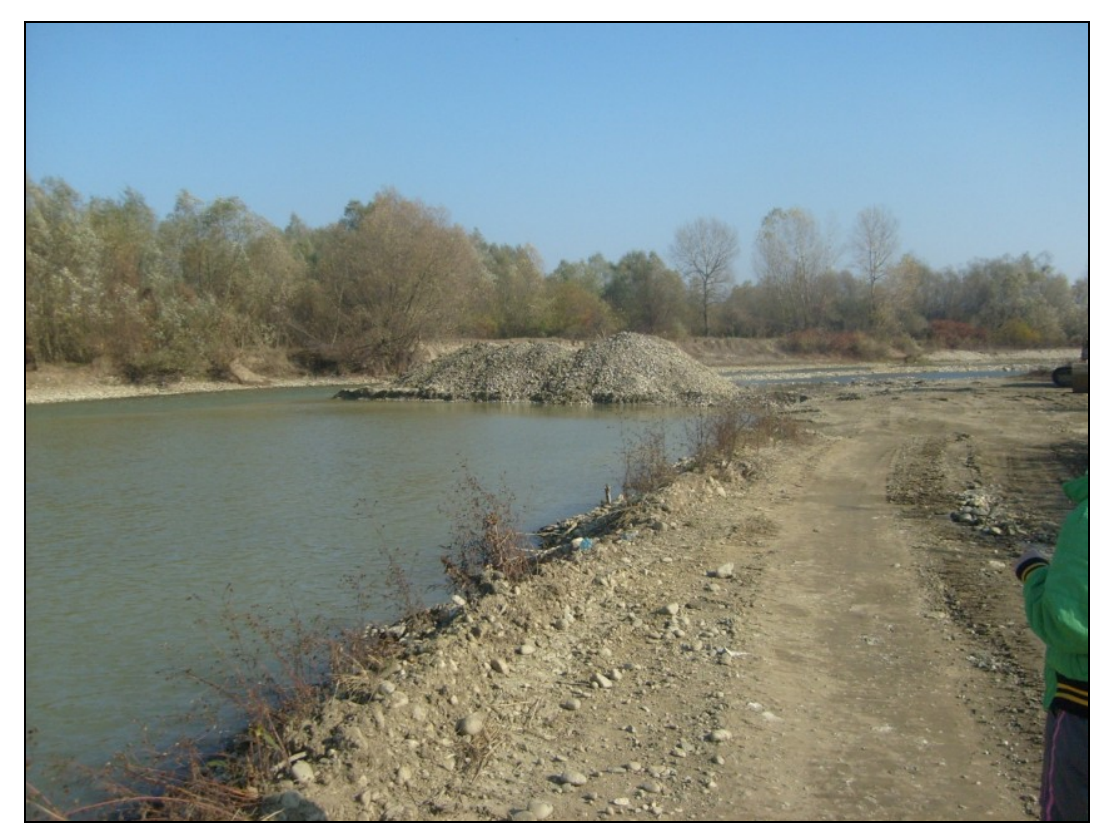

Figure 22: Aggressive exploitation of the substrate with lotic habitat damage.

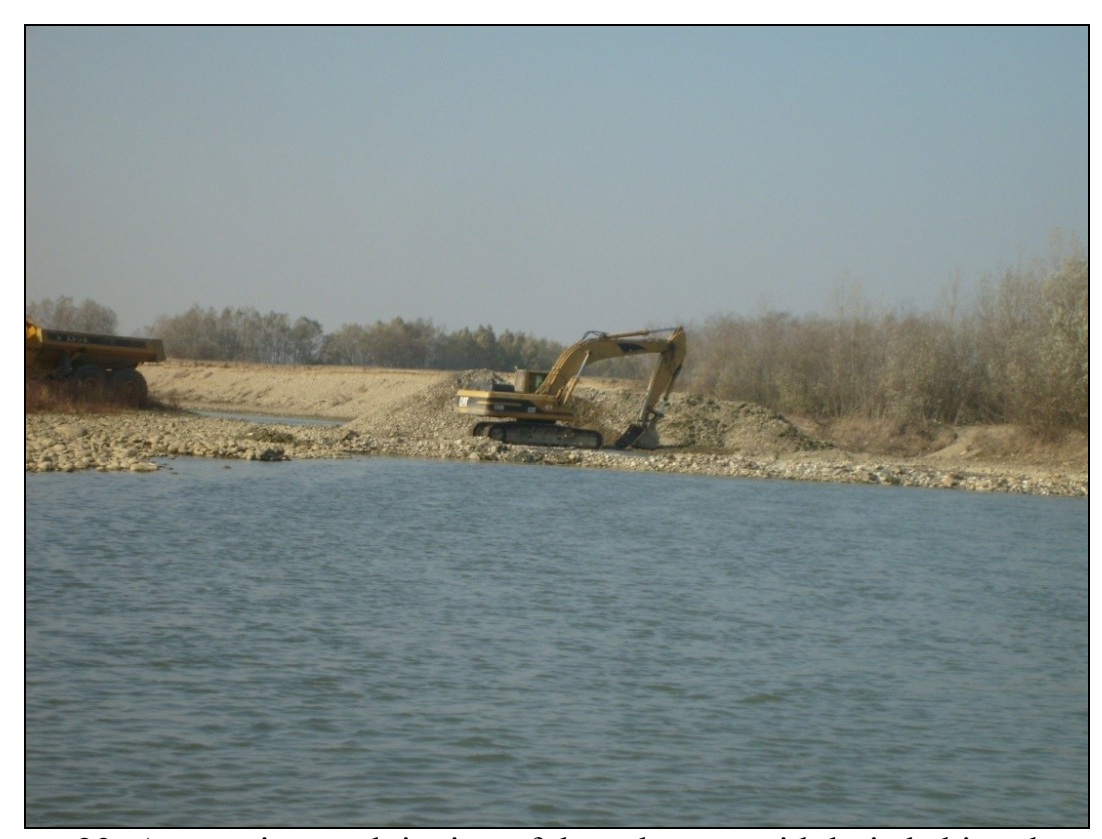

Figure 23: Aggressive exploitation of the substrate with lotic habitat damage. 
In the sampling area located in the proximity of the Lugojel locality (C16) (Fig. 24), the mud became dominant as a substrate (Fig. 25) were collected and identified the following species: Barbus barbus (41.67\%), Perca fluviatilis (13.1\%), Squalius cephalus (13.1\%), Alburnoides bipunctatus (10.71\%), Barbus meridionalis (5.95\%), Alburnus alburnus (3.57\%), Gobio gobio (2.38\%), Carasius gibelio (2.38\%), Sabanejewia balcanica (1.19\%), Romanogobio banaticus (1.19\%), Pseudorasbora parva (1.19\%), Rhodeus sericeus $(1.19 \%)$, Chondrostoma nasus (1.19\%), Scardinius erythrophthalmus (1.19\%), Esox lucius (q), Squalius aspius (q). The increasing number of fish species is determined by the decline of the ballast mining impact in the upstream and passage of the river in a high ichthyological diversity river sector.

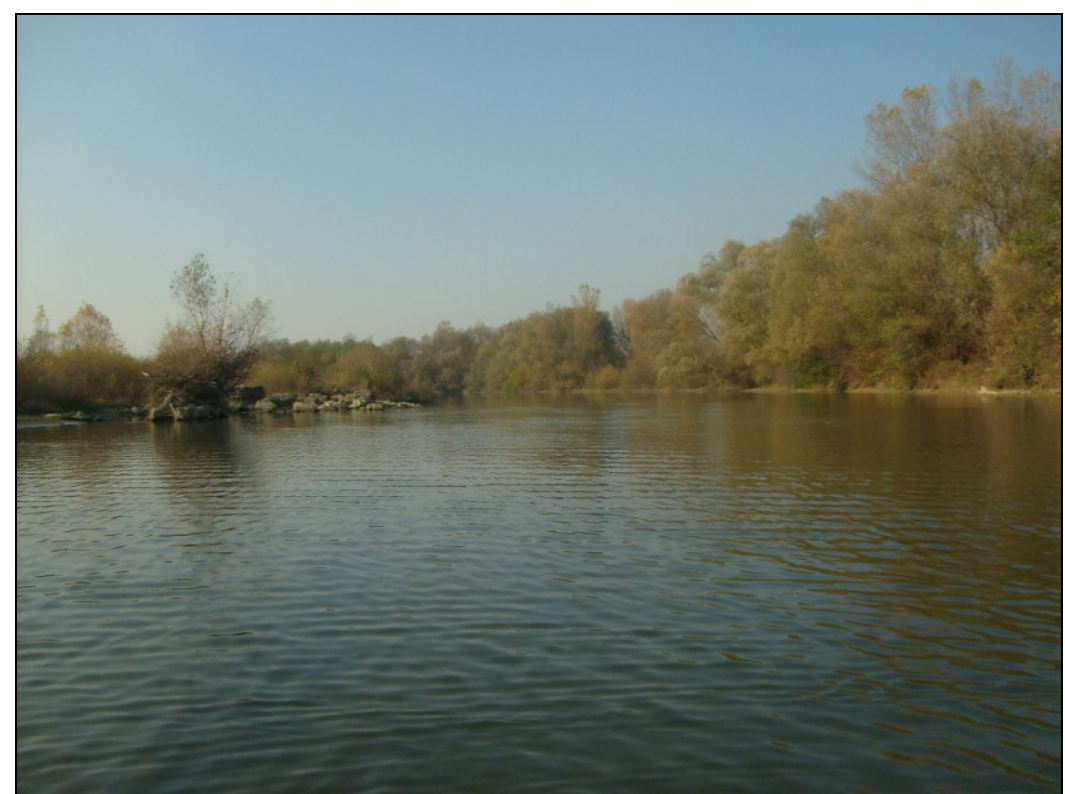

Figure 24: Characteristic habitat for Timiş River, near Lugojel locality.

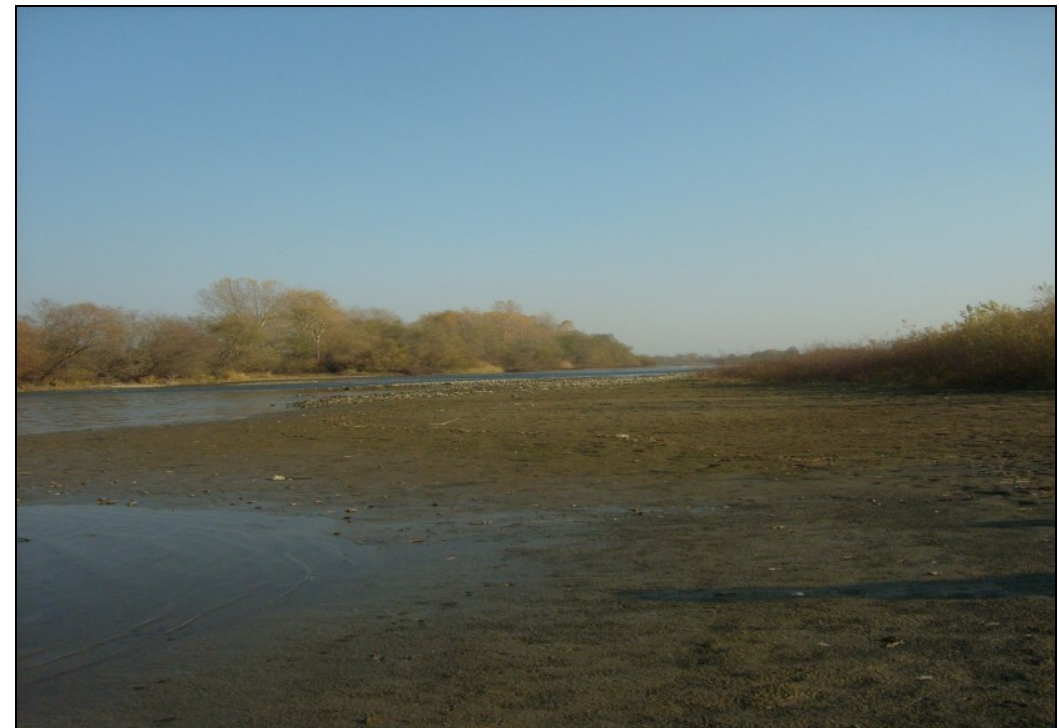

Figure 25: River sector with dominant mudy substrate near Lugojel locality. 
In the sampling station located at Coştei (C17), downstream from the Lugoj town were obtained the following total abundances: Barbus barbus (41.91\%), Squalius cephalus 16.18\%, Perca fluviatilis (12.5\%), Alburnoides bipunctatus (12.5\%), Alburnus alburnus (3.68\%), Gobio gobio (3.68\%), Carasius auratus (2.94\%), Chondrostoma nasus (1.47\%), Barbus meridionalis (0.74\%), Sabanejewia balcanica (0.74\%), Pseudorasbora parva $(0.74 \%)$, Rhodeus sericeus (0.74\%), Scardinius erythrophthalmus (0.74\%), Cobitis taenia (0.74\%), Lepomis gibbosus $(0.74 \%)$. The specific diversity is affected by the oversized (in the last 10 years) dam towards the hydraulic node Coştei (Fig. 26), who is here since 1758. The near Timiş-Bega channel, collect the majority, and sometimes all the water of Timiş River to deviate it through Bega River (Fig. 27).

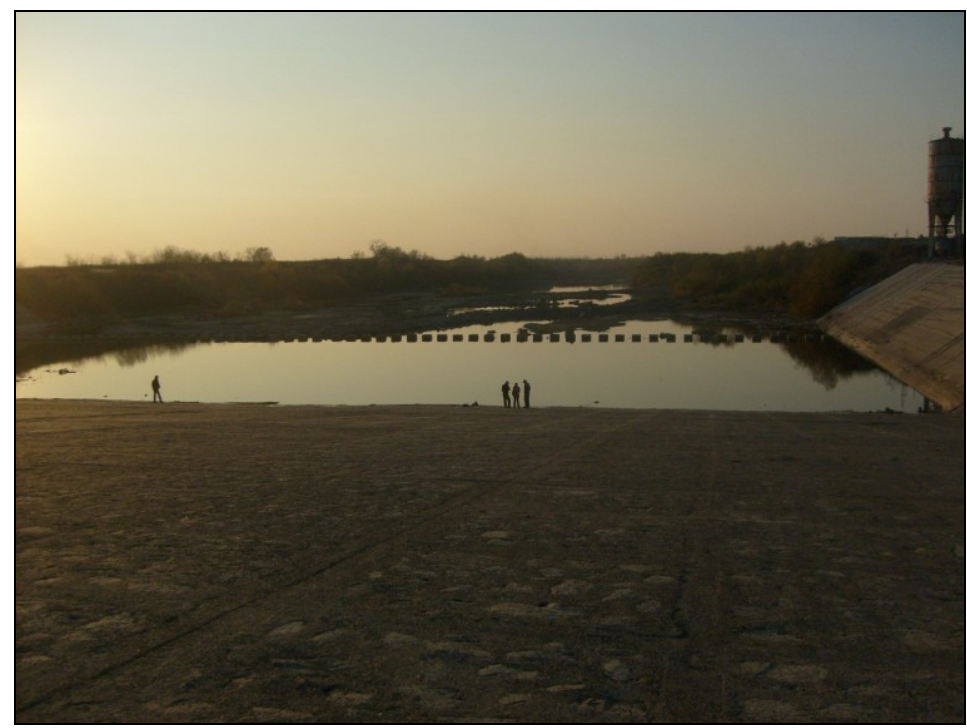

Figure 26. Major lotic discontinuity at Coşteiu Dam; view from the dam to downstream.

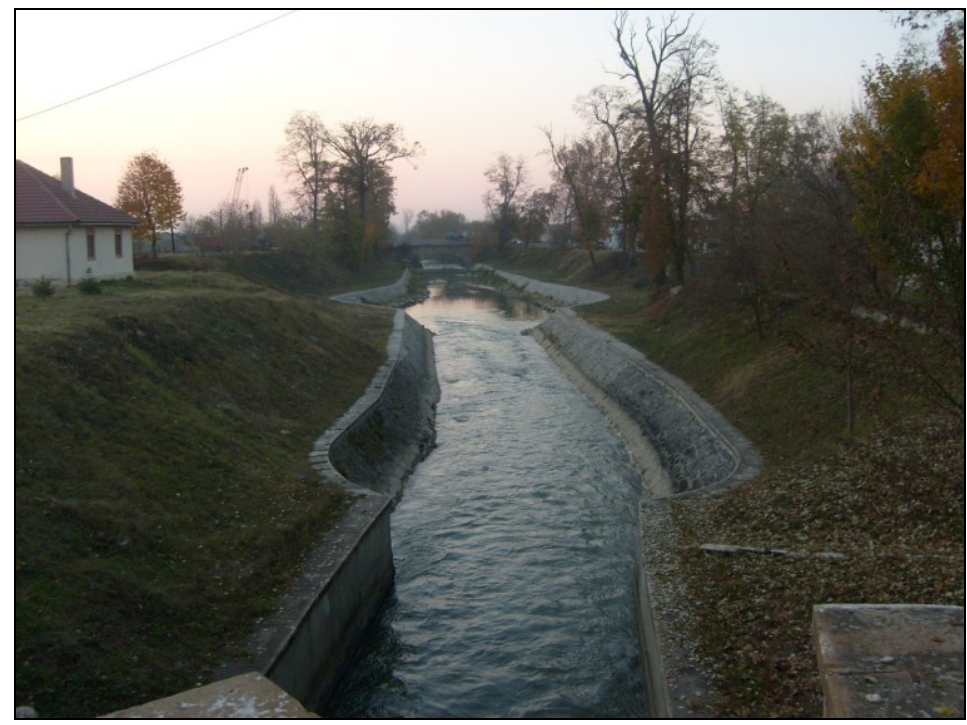

Figure 27: The Timiş-Bega deviation/channel. 
In the sampling area located between Topolovăţu Mare and Hitiaş localities $(\mathbf{C 1 8})$ (Fig. 28) were identified the following species: Barbus barbus (23.2\%), Romanogobio banaticus (17.01\%), Squalius cephalus (13.4\%), Sabanejewia balcanica (11.86\%), Alburnoides bipunctatus (8.25\%), Perca fluviatilis (8.25\%), Alburnus alburnus (4.64\%), Scardinius erythrophthalmus (2.58\%), Lota lota (2.58\%), Gobio gobio (2.06\%), Romanogobio albipinnatus (1.55\%), Carassius gibelio (1.55\%), Cobitis taenia (1.03\%), Rhodeus sericeus (1.03\%), Pseudorasbora parva (0.52\%), Vimba vimba (0.52\%), Silurus glanis (q), Ictalurus nebulosus (q), Cyprinus carpio (q), Lepomis gibbosus (q), Acerina cernua (q), Aspro streber (q), Gymnocephalus schraetzer (q), Abramis brama (q), Esox lucius (q), Rutilus rutilus (q) and Aspius aspius (q). The diversity of fish species shows a good lotic ecosystem status.

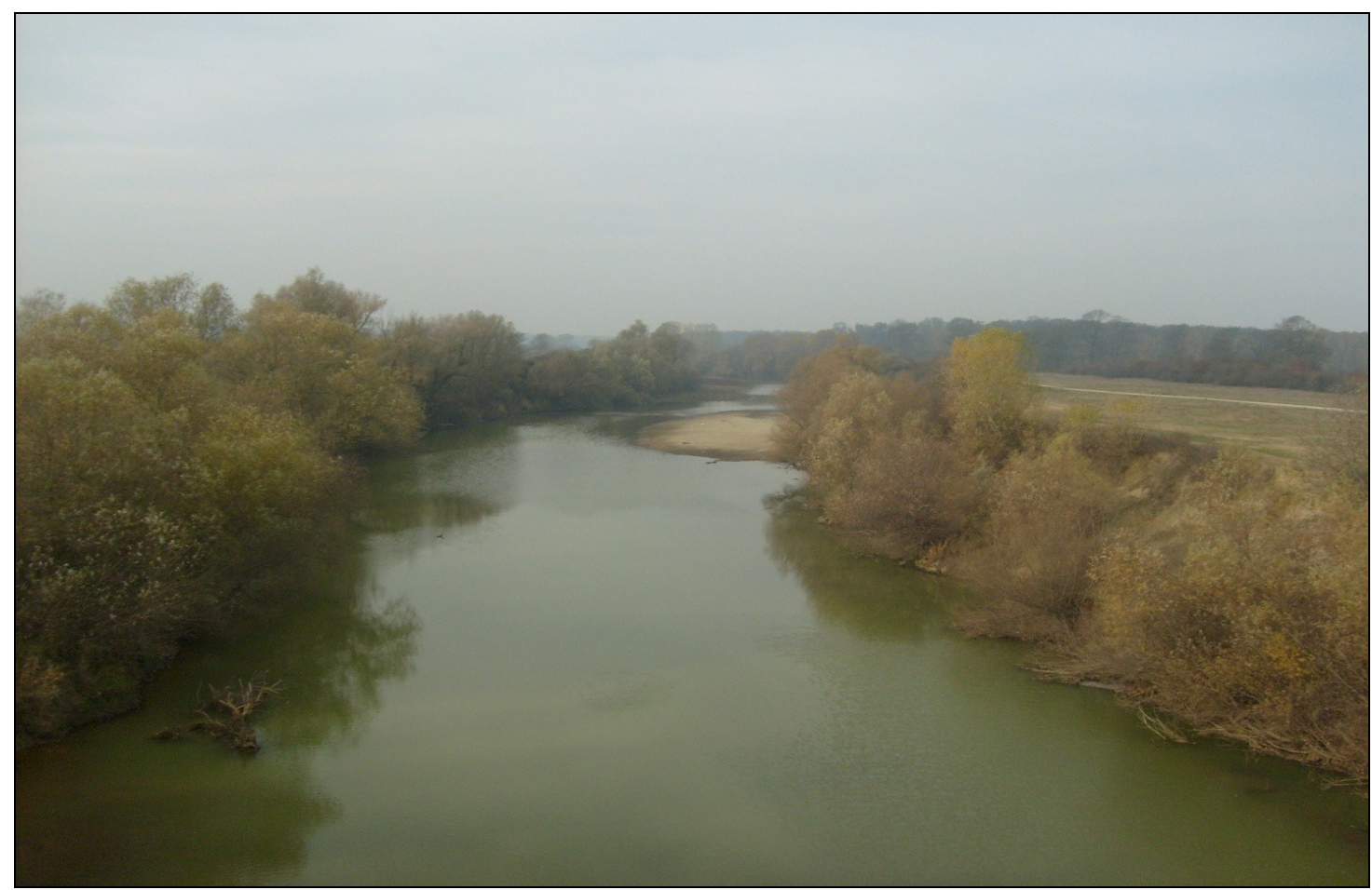

Figure 28: Characteristic habitat for Timiş River betweenTopolovăţu Mare and Hitiaş.

In the sampling station located at SSag (C19), were obtained the following total abundances (the values represent the average of total abundances obtained in each trip of ichtyofauna sampling in this section): Sabanejewia balcanica (21.3\%), Romanogobio banaticus (16.96\%), Barbus barbus (14.35\%), Squalius cephalus (12.61\%), Perca fluviatilis (7.39), Alburnoides bipunctatus (6.09\%), Alburnus alburnus (5.22\%), Scardinius erythrophthalmus (3.04\%), Lota lota (3.04\%), Romanogobio albipinnatus (2.17\%), Gobio gobio (1.74\%), Pseudorasbora parva (1.3\%), Rhodeus sericeus (1.3\%), Cobitis taenia $(1.3 \%)$, Lepomis gibbosus $(0.87 \%)$, Vimba vimba (0.43\%), Cyprinius carpio $(0.43 \%)$, Carassius auratus (0.43\%), Acerina cernua (q), Silurus glanis (q), Ictalurus nebulosus (q), Gymnocephalus schraetzer (q), Aspro streber (q), Chondrostoma nasus (q), Abramis brama (q), Streber lucioperca (q), Esox lucius (q), Aspius aspius (q), Rutilus rutilus (q); the diversity of fish species showing a good lotic ecosystem both with long natural sectors (Fig. 29) and anthropogenicaly modified short sectos (Fig. 30). 


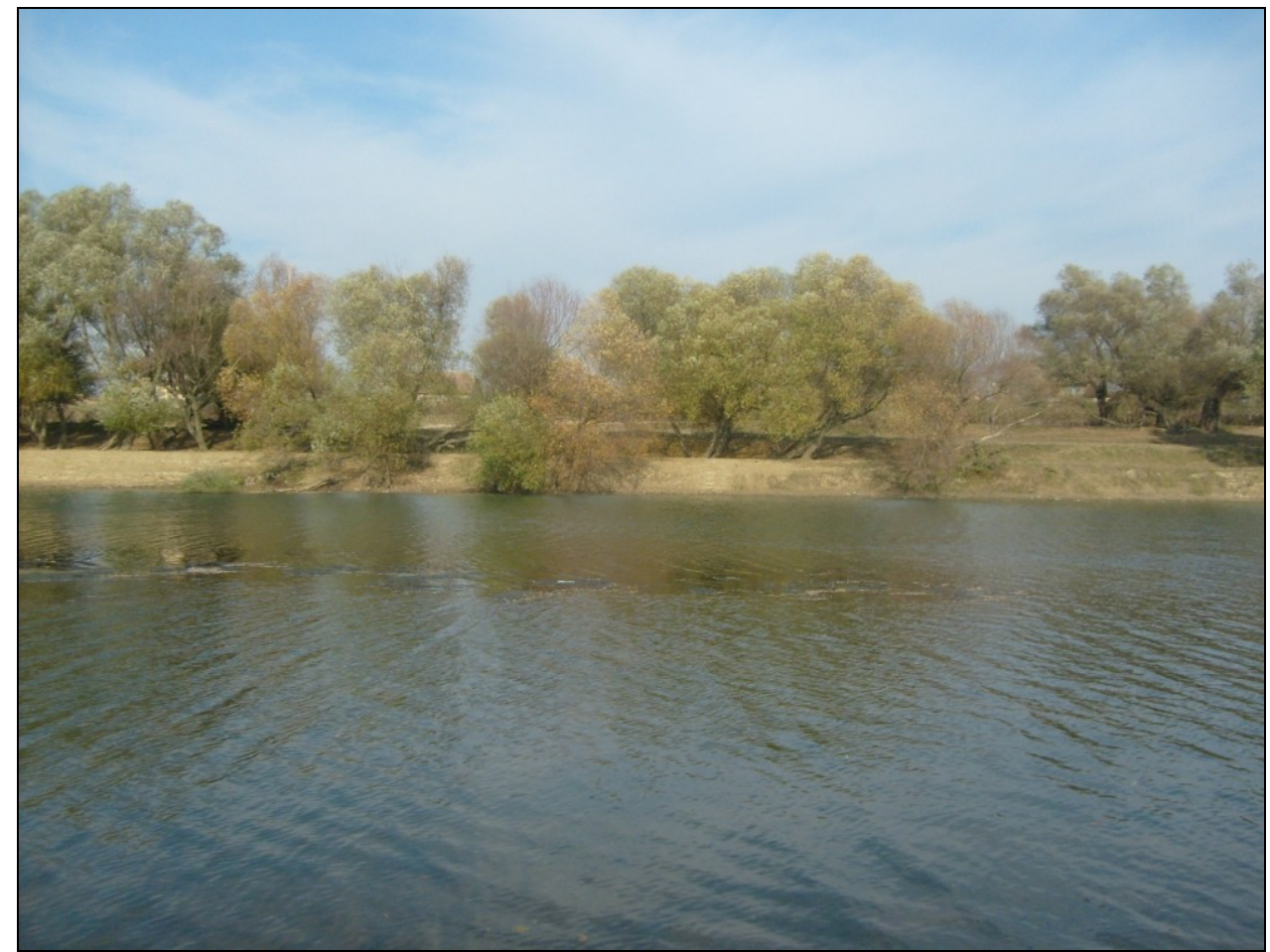

Figure 29. Characteristic habitat for Timiş River at Şag.

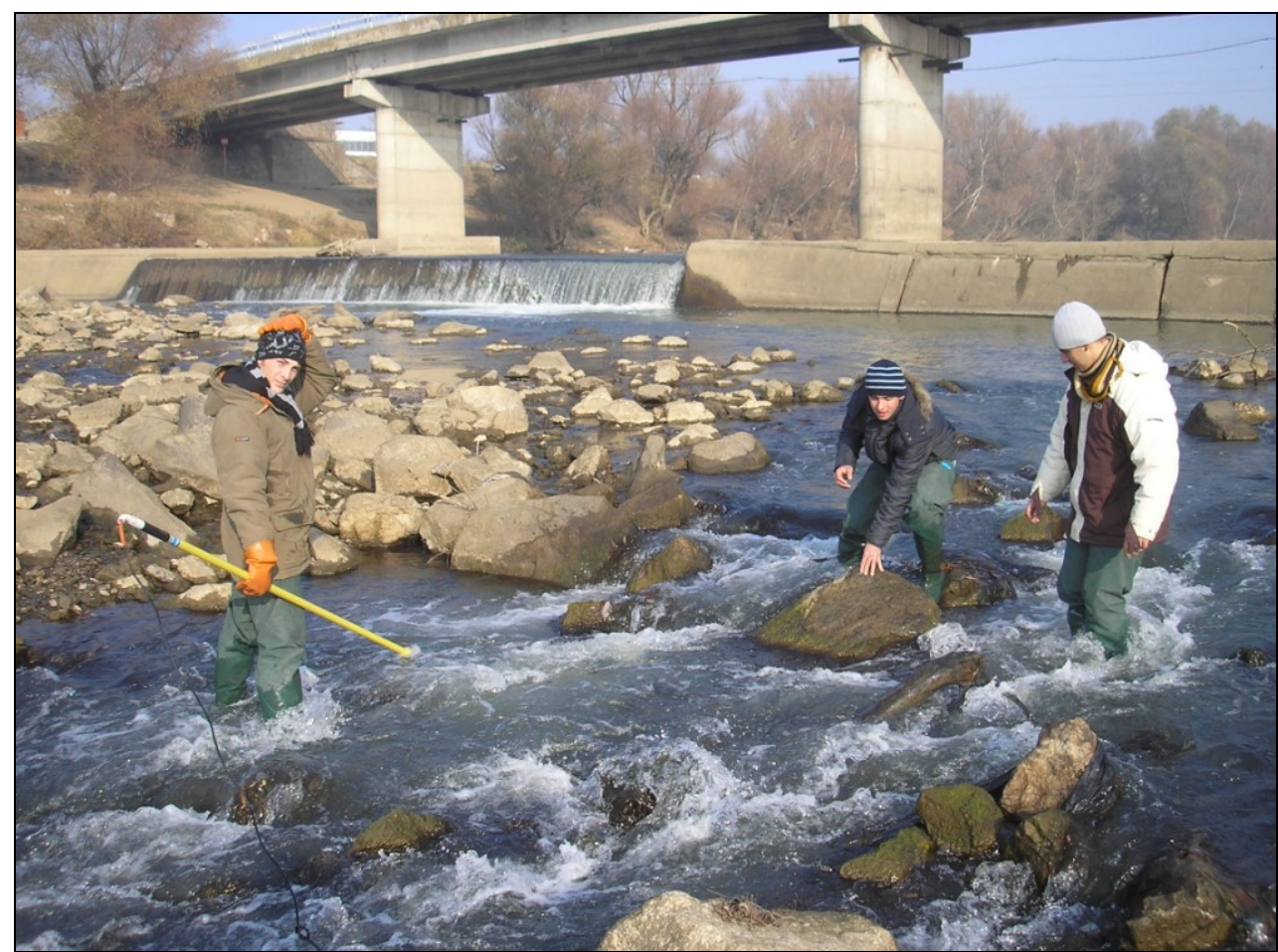

Figure 30: Affected river sector following hydrotechnical works related to a bridge. 
Near the locality Cebza (C20) (Fig. 31) were identified: Romanogobio banaticus (22.22\%), Barbus barbus (15.28\%), Squalius cephalus (14.58\%), Alburnus alburnus (11.11\%), Perca fluviatilis (10.42\%), Lepomis gibbosus (5.56\%), Gobio gobio (4.17\%), Scardinius erythrophthalmus (4.17\%), Romanogobio albipinnatus (2.78\%), Pseudorasbora parva (2.08\%), Zingel zingel (1.39\%), Sabanejewia aurata balcanica $(0.69 \%)$, Cyprinus carpio $(0.69 \%)$, Carassius auratus (0.69\%), Sabanejewia balcanica (0.69\%), Rhodeus sericeus (0.69\%), Cobitis taenia (0.69\%), Alburnoides bipunctatus (0.69\%), Vimba vimba (0.69\%), Gymnocephalus cernuus (0.69\%), Zingel streber (0.69\%), Chondrostoma nasus (q), Silurus glanis (q), Ictalurus nebulosus (q), Lota lota (q) (Fig. 32), Blicca bjoerkna (q), Abramis brama (q), Silurus glanis (q), Ictalurus nebulosus (q), Streber lucioperca (q), Esox lucius (q), Aspius aspius (q); the diversity of fish species show a good lotic ecosystem.

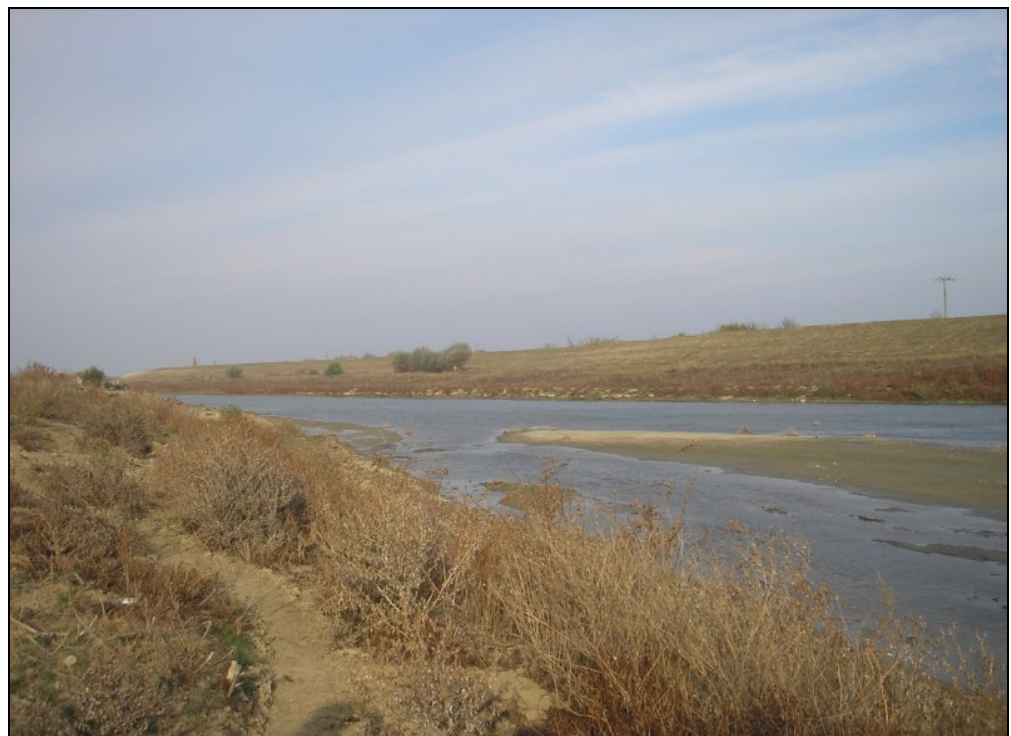

Figure 31: Characteristic habitat for Timiş River, in the proximity of the locality Cebza.

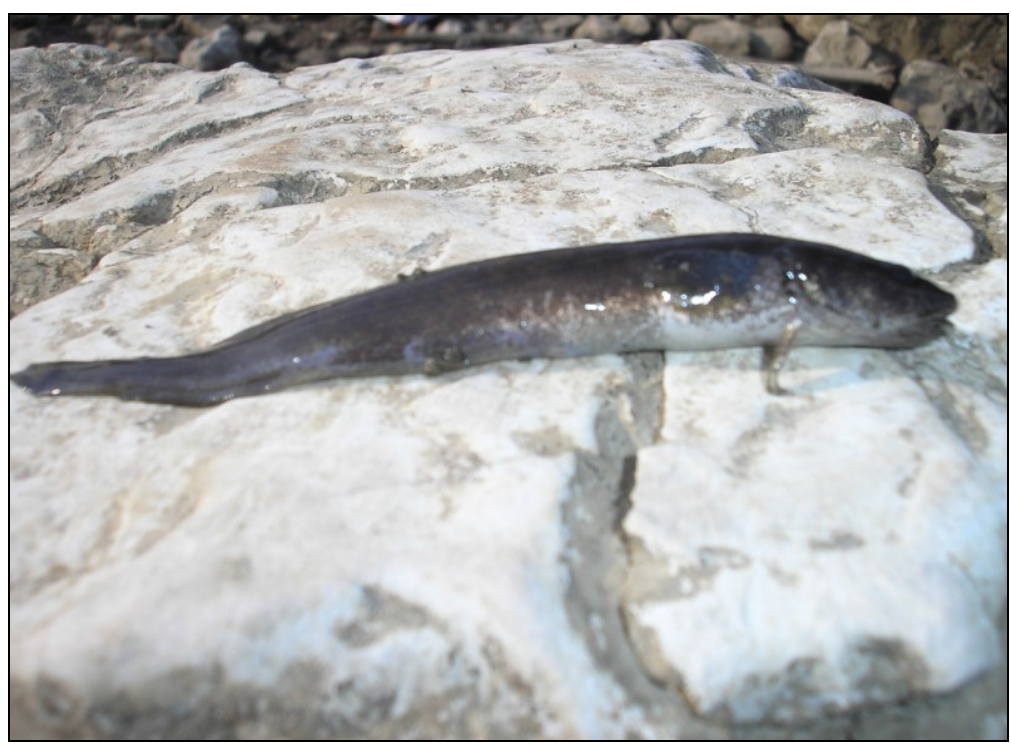

Figure 32. Lota lota. 
In the sampling station located at Cruceni (C21) (Fig. 33), were obtained the following total abundances: Alburnus alburnus (17.54\%), Squalius cephalus (15.79\%), Lepomis gibbosus (13.16\%), Perca fluviatilis (12.28\%), Barbus barbus (9.65\%), Zingel zingel (7.02\%), Gobio gobio (6.14\%), Scardinius erythrophthalmus (5.26\%), Gymnocephalus cernua (5.26\%), Zingel streber (4.39\%), Pseudorasbora parva (2.63\%), Gymnocephalus schraetzer $(0.88 \%)$ (Fig. 34); the lower ichthyological diversity can be attributed to increased anthropogenic uniformity of habitat.

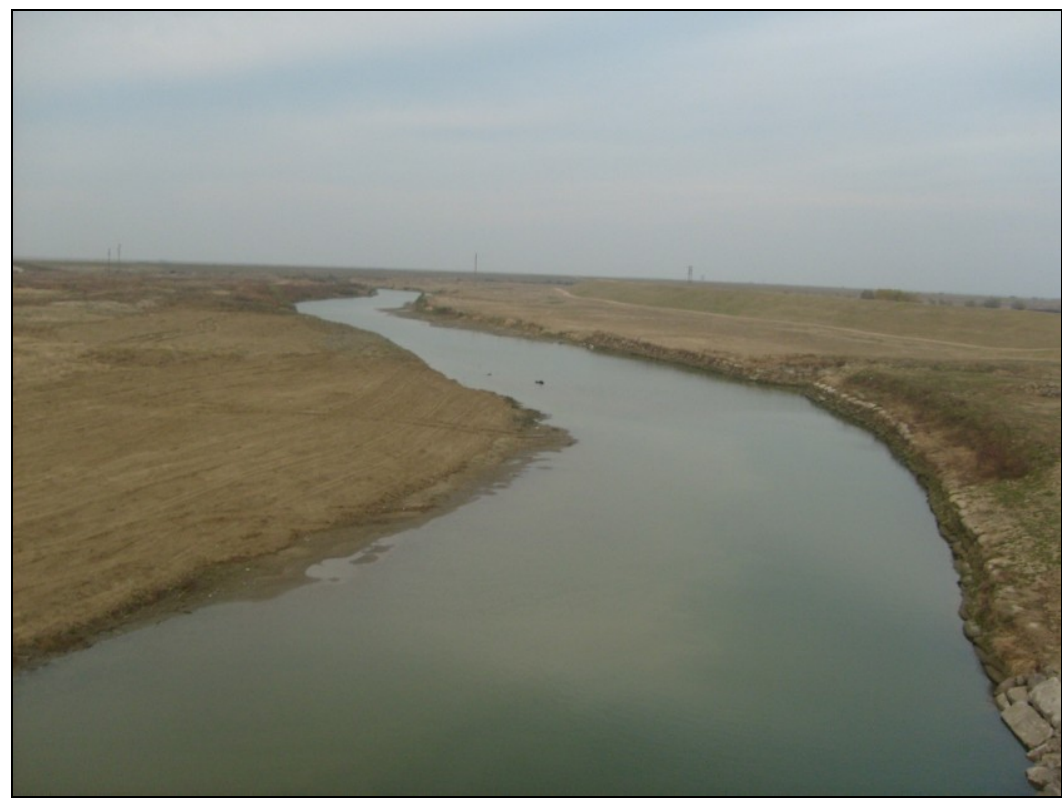

Figure 33: Timiş River anthropogenic modified habitat, at Cruceni.

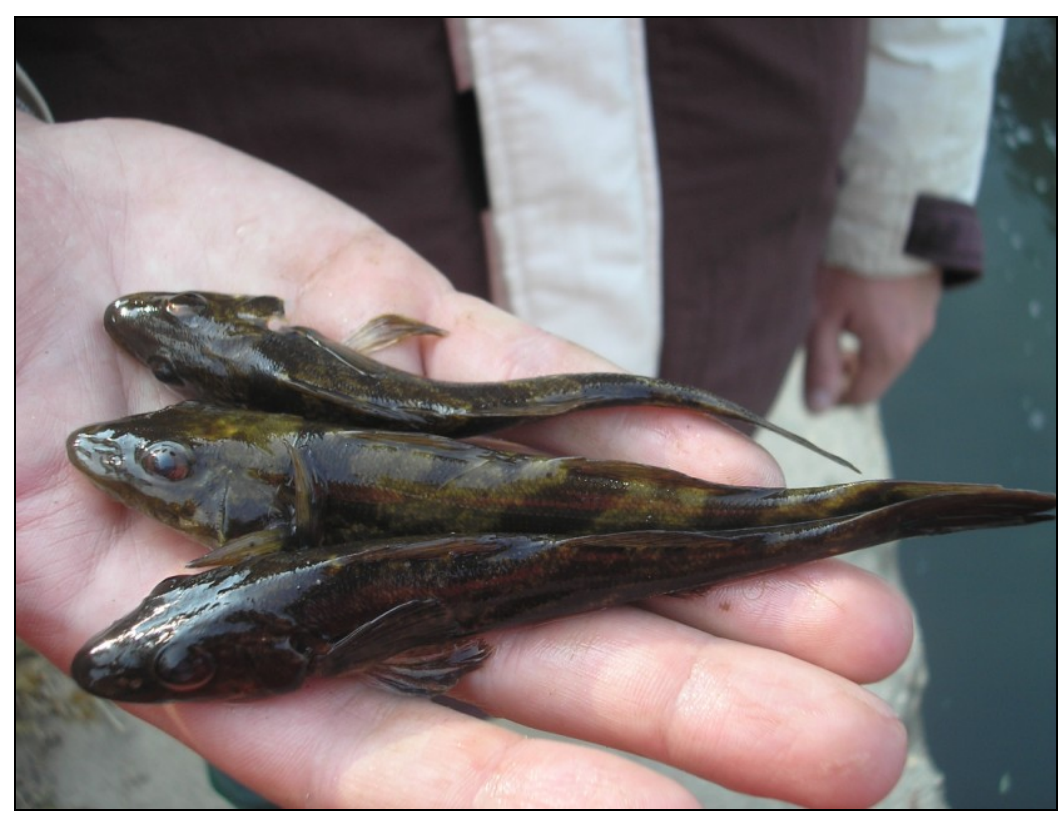

Figure 34: Zingel streber. 


\section{DISCUSSIONS}

The identified fish communities similarity (Fig. 35) reveal the fact that almost the whole river course is more or less (with few exceptions) negatively damaged by the human impact, situation which disturb in different degrees the natural lotic longitudinal connectivity induced by the regional and local relief (Fig. 36), in respect of habitats and the associated ichtiocenosis. The fish communities similarities were obtained only basing on the quantitative (electrofishing) samples results and not on the qualitative samples results (q) too, based on other qualitative methods (angling and/or net traps fishing).

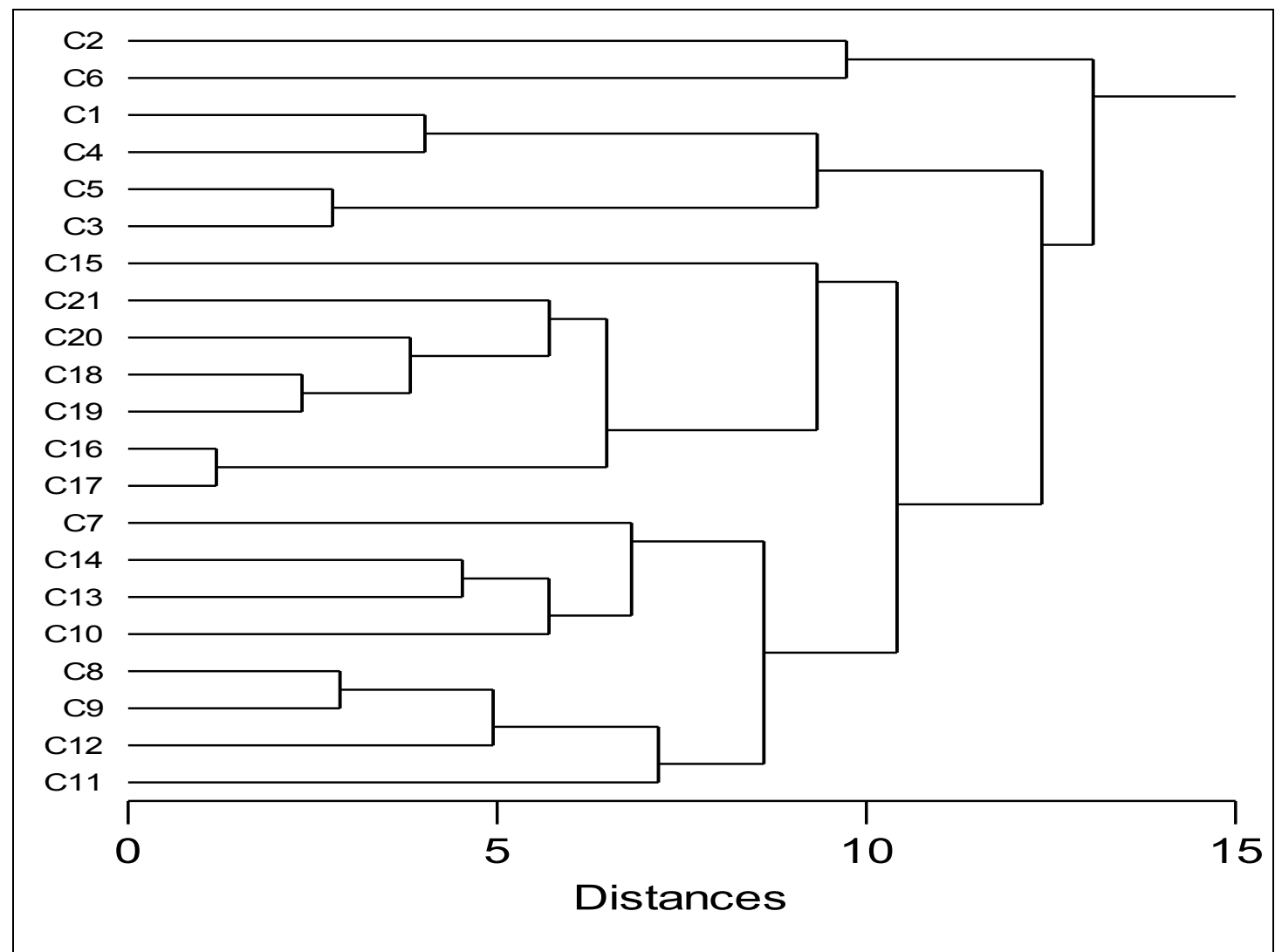

Figure 35: Timiș River fish communities similarity.

C1-C6 sector (Fig. 35) the mountain and sub-mountain (mainly schsists geological substratum) (Fig. 36) related rivers sectors of Timiș River, with different/variable ichtiological characteristics among them related with different types of human impact presence.

C1 (Semenic Stream) and C4 (Grădiște Stream) sectors (Fig. 35) are similar in respect of the fish communities mainly due to the fact that their sources and upper sectors are protected by natural conservation areas (Semenic-Cheile Carașului National Park).

C2 (Brebu Nou Stream section) and C6 (upstream Teregova locality sector) sectors (Fig. 35) seem to be similar from the ichthyofauna point of view because these sectors are influenced in similar ways by the presence of anthropogenicaly pools in the riverbed.

C3 (Lung Stream section) and C5 (downstream Trei Ape Dam) sectors (Fig. 35) are similar apparently based on their natural (in the first case) and antropogenical (in the second case) variability and scarcity of water flow especially in the drought seasons. 


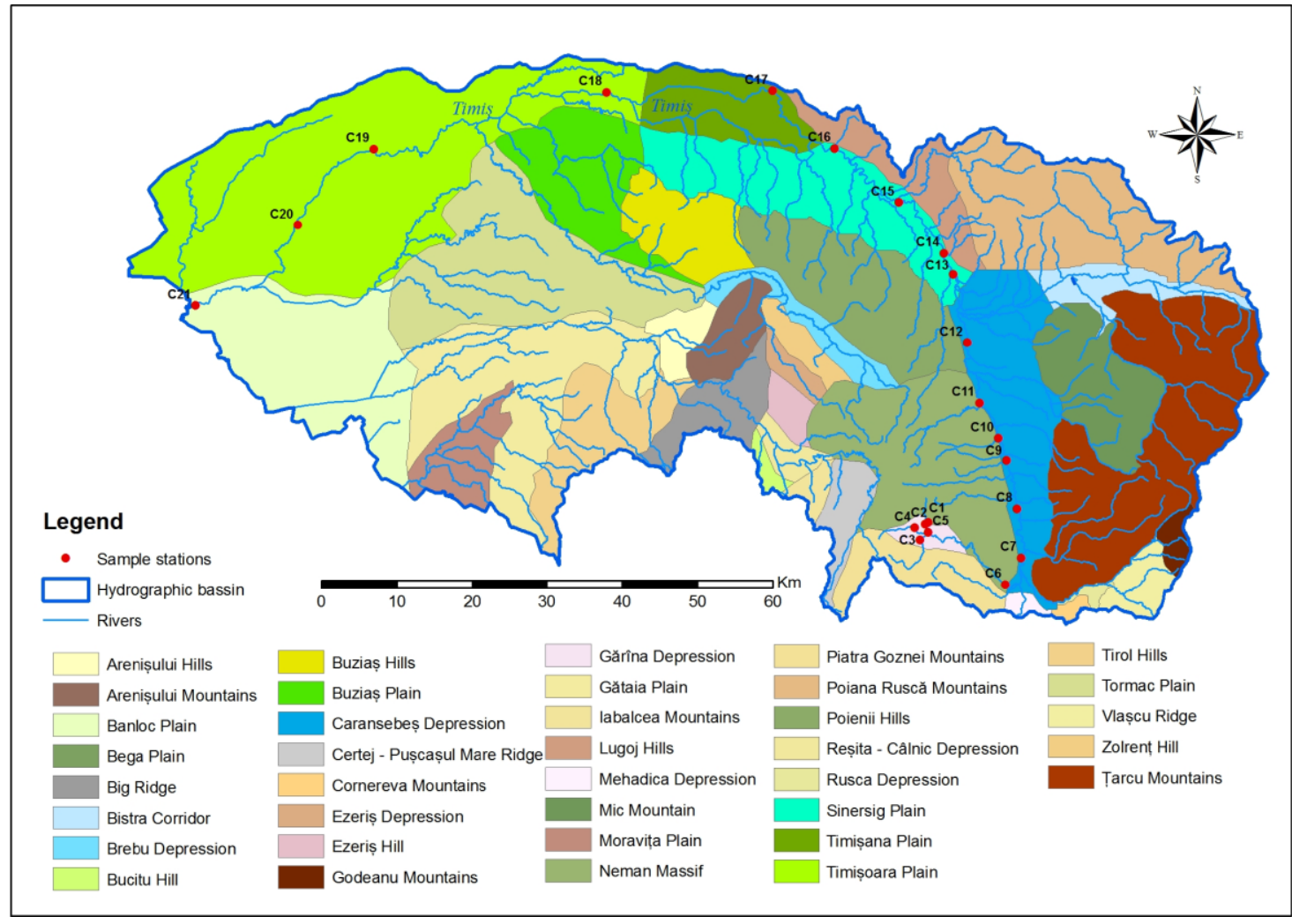

Figure 36: Timiș River main geographical units and samplig stations

C7-C12 sector obviously highlight the entering of Timiș River in the Caransebeş Depression area (Fig. 36), habitats reflected in the ichthyofauna structure. This sector is prolonged till C14 (Fig. 35) from the fish fauna point of view because of Bistra River tributary, received here, bringing a good quality water and also upper river characteristic fish species, prolonging/keeping this Timiş River sector in an upper fish fauna characteristic diversity structure. The very low human impact here helps this situation too.

C7 (Teregova Gorges section) was individualized (Fig. 35) because of the best natural habitats and associated related fish community structure, due to its relative geographic isolation and may be because is proper protected by an upper Timiş River Natura 2000 site.

C8 (Sadova section) and C9 (Petroșnița section) represent a similar river sector because the river gets out of the Teregova Gorges geographical relative isolation and enter in a sector where the river is influenced by the local riverine human impact (the villages are localised on the river course) and ecologically inadequate water flow management due to some hydrotechnical works present on the upper eastern main tributaries.

C11-12 sector (Fig. 35) is obviously and significantly negatively affected by the human activities (riverbed mineral exploitations, pollution, embankments, riverine vegetation destruction, etc.) of the Caransebeş locality.

C13-14 fish fauna similarity (Fig. 35) is determined by the enter of the Timiş River in the Sinersig Plain (Fig. 36) and moustly to the effect of the Bistra River confluence, in terms of water quality and fish species (Bănăduc, unpublished data). 
C15 sector is obviously individualised (Fig. 35) due to the decrease of the number of fish species, due to aggressive (intensive and extensive) exploitation of the river substrate.

C16-17 fish associations similarity (Fig. 35) can be based on their common position in Timişana Plain (Fig. 36.), can be aspected that this similarity to decrease in the future due to the local dam (Coştei hydraulic node) oversized in the last few years.

C18-21 sector have a relative fish species diversity similarity (Fig. 35) due to these sections localisation in the lowest Romanian geographical units of the Timiş River (Timişoara Plain) (Fig. 36.). The quality of the habitats still separate them in two, C18-C19 with better habitats and $\mathrm{C} 20-\mathrm{C} 21$ with habitats more affected mainly by human hidrotechnical works, especially in the lowest sampling station.

\section{CONCLUSIONS}

The length and direction of flow of the Timiş River, its position and the surface of its hydrographic basin, the multitude of anthropogenic impacts make one of the most complex medium size river in Romanian Carpathian Basin regarding the fish fauna.

The identified fish communities structure variation can be explained based on the geographic units characteristics and human activities impact. The actual fish fauna of this river suffered significant modifications in the last half of the century, and its dynamic it is still not in an equilibrium state mainly due to the human impact dynamic.

This fish fauna assessment should be continued through monitoring in subsequent years in order to grasp the dynamic elements, both of fish structurally stable populations and associations, and of those structurally unstable.

In this river basin management plan must be implemented a fish monitoring system with at least 12 permanent seasonal monitoring stations (one for every identified similarity fish species groups) so that the conclusions can have the degree of accuracy required to the optimal management at the level of the entire river and subsequently at the level of the entire basin.

\section{ACKNOWLEDGMENTS}

This paper results are based on the scientific field campaigns of the project "Study of the quality of Timiş water and registry of polluters source to border" (IV.1.2), a Phare CBS project, no. 411 - 90964/30.12.2010/07, of "Lucian Blaga" University, Faculty of Sceinces, financed by the European Community. The authors thank to the GIS expert Gheorghe L. for figure number 36 and the following students for their help in some of the the field campaignes: Stroilă V., Mărginean M. and Răchită R.. A good thought to my childhood and teenage best friend Adam H. with which we discovered together the wonderful Timiş River.

\section{REFERENCES}

1. Arba A., 2013 - Extreme Hydro-Meteorological phenomena on the hydrographical basin of Timiş (1965-2009), Riscuri şi Catastrofe, XII, 12, 1, 99-112.

2. Badea L. and Bugă D. (coord.), 1992 - Geografia României IV, Regiunile pericarpatice, Edit. Academiei Române, București, 580. (in Romanian)

3. Bănărescu P. M., 1964 - Fauna R.P.R., Pisces-Osteichthyes, (Peşti ganoizi şi osoşi), XIII, Edit. Academiei Române, București, 959. (in Romanian)

4. Costea M., 2006 - Riscul la inundaţii. Impactul în peisaj, în Hidrologie aplicată, Ştef, V. and Costea M. (eds.), Edit. Universității „Lucian Blaga” din Sibiu, 205-240. (in Romanian)

5. Diaconu C., 1971 - Râurile României. Monografie, Edit. INMH, București, 494. (in Romanian)

6. Linc R., 2002 - Culoarul Timiş - Cerna, Edit. Universităţii din Oradea. (in Romanian)

7. Oancea D. and Velcea V. (coord.), 1987 - Geografia României, III, Carpații şi Depresiunea Transilvaniei, Edit. Academiei, București, 647. (in Romanian).

8. Udo J., Aldescu C., Dumitrache R. and Luca L., 2011 - INHGA, 109-122. (in Romanian)

9. Ujvari I., 1972 - Geografia apelor României, Edit. Științifică, București, 577. (in Romanian) 